\title{
FIGURA KRWIOPIJCY W DYSKURSIE RELIGIJNYM, NARODOWYM I LEWICOWYM POLSKI ROKU 1945/1946. STUDIUM Z ANTROPOLOGII HISTORYCZNEJ
}

W śród archetypowych metafor uruchamianych przez kryzysy' znajduje się wyobrażenie czarownika-wampira, który wnika do wnętrza zbiorowości i pozbawia ją substancji życiowej, „pozostawiając za sobą puste skorupy ciała" (Mary Douglas) ${ }^{2}$. Uniwersalność figury bierze się z jej prostoty. W minimalnej strukturze sprowadza się ona do zakazanego ruchu w obrębie strzeżonej granicy "wnętrze"/ "zewnętrze", często wyrażającego się W czynności "kłucia" lub "ssania krwi”.

Można wskazać wiele mniej lub bardziej niewinnych zastosowań, jakie znalazła ona w polskim dyskursie politycznym ostatnich lat. W roku 2007 polski premier Donald Tusk użył jej przeciw Jarosławowi Kaczyńskiemu, mówiąc, że „PiS niczym wampir żywi się lękiem i złem,

1 Zob. M. Kurkowska-Budzan, Antykomunistyczne podziemie zbrojne na Białostocczyźnie, Kraków 2009, s. 41.

2 M. Douglas, Symbole naturalne, przeł. E. Dżurak, Kraków 2005, s. 151. Zob. J. Tokarska-Bakir, Legendy o krwi. Antropologia przesądu, Warszawa 2008 (dalej: LK), s. 156. Biologicznym podłożem metafory Krwiopijcy jest pamięć zwierzęcych przodków człowieka, zagrożonych przez jadowite węże, insekty i pasożyty. Zob. A. Wierciński, Magia i religia. Szkice z antropologii religii, Kraków 2000.
Prof. dr hab. Joanna TOKARSKA-BAKIR jest pracownikiem naukowym w Katedrze Historii Idei i Antropologii Kultury w Instytucie Stosowanych Nauk Spolecznych Uniwersytetu Warszawskiego oraz w Instytucie Slawistyki PAN. joannatb@poczta.onet.pl 
które tkwią w każdym z nas“3. Rok później użył jej szef Instytutu Pamięci Narodowej, Janusz Kurtyka, który określił autora Strachu, Jana Tomasza Grossa, jako „wampira polskiej historiografii" ${ }^{4}$.

W tym tekście zajmę się genealogią figury Krwiopijcy i rolą, jaką odegrała ona w organizacji wyobraźni Polaków w pierwszych dwóch latach po II wojnie światowej.

Swój morderczy potencjał figura Krwiopijcy ujawniła w fali pogromowej uruchomionej pogłoskami o żydowskich mordach rytualnych, jaka przetoczyła się w przez kraj w latach 1945-1946. Rozpoczęła się ona w Chełmie, gdzie na przełomie marca i kwietnia roku 1945 milicja oskarżyła kilku Żydów o wytoczenie krwi „z chłopca chrześcijańskiego“ i gdzie wobec jed nego z oskarżonych zastosowano tortury. Następnie pogłoskę o krwi odnotowano w Rzeszowie; tam podłożem ekscesów (14-15 VI 1945) stała się niewyjaśnione zabójstwo dziewczynki, o które oskarżono rabina. W dwa miesiące później (11 VIII 1945) plotka odezwała się w Krakowie, gdzie tłum rzucił się na Żydów, gdy z synagogi przy ul. Miodowej wybiegł chłopak, krzycząc, że w środku znajdują się zwłoki "dzieci chrześcijańskich". W czerwcu tego roku podobne oskarżenia pojawiły się jeszcze w Przemyślu, w sierpniu w Kielcach, Radomsku, Łodzi, Zwoleniu, Bydgoszczy i ponownie w Chełmie. Największe rozruchy na podłożu pogłoski o mordzie miały miejsce w Kielcach, gdzie w dniach 4-5 VII 1946 r. zginęło w sumie 42 Żydów. Po osiągnięciu apogeum fala pogłosek pogromowych nie opadła. Rozlała się na kolejne polskie miasteczka, obejmując Tarnów, ponownie Kraków, Częstochowę, Radom, Ostrowiec Świętokrzyski, Białobrzegi, Dęblin, ponownie Łódź, a także kilkanaście innych miejscowości.

\section{TRZY WCIELENIA KRWIOPIJCY}

W powojennej historii Polski można wykryć ślady trzech odmian tej figury: religijną, narodową i lewicową.

Pierwsze z wcieleń archetypu Krwiopijcy, figura religijna, w czasach wczesnonowożytnych wyobrażała Krwiopijcę jako Innego, najczęściej Żyda (choć w tej roli mógł też niekiedy występować ",heretyk": husyta ${ }^{5}$, protestant ${ }^{6}$ lub unita7) jako antagonistę katolików, porywającego i kaleczącego ich świętość, hostię lub „dziecko katolickie".

Żyd jest tu dosłownie krwiopijcą, porywa bowiem dziecko i jego krwi używa do macy na Święto Przaśników. Ten motyw mityczny stanowił (obok mitu o profanacji hostii) podstawowy składnik tzw. legendy o krwi ${ }^{8}$. Jej schemat fabularny można sprowadzić do sekwencji:

szkodzenie - walka - zwycięstwo / zdemaskowanie Antagonisty - ukaranie,

3 Donald Tusk: Nie będzie koalicji z PiS Kaczyńskiego "Gazeta Wyborcza", 1-2/09/2007.

4 Kurtyka: Gross to wampir historiografii, "Gazeta "Wyborcza", 10/01/2008. W Polsce przynajmniej od lat 60. XX wieku mianem wampira określa się seryjnych morderców, zob. http://lublin.gazeta.pl/lublin/1,35640,7746531,_Wampir_pozywa_radio_za_wampira_Chce_pol_miliona.html

5 Por. użycie tradycyjnej retoryki antyżydowskiej w kontekście husyckim w programie obrazu Vir Dolorum, śląski obraz z Brzegu z roku 1443, zob. T. Dobrzeniecki, Catalogue of the Medieval Painting, Warszawa 1977, ilustracja 64, s. 227-228.

6 Zob. oskarżenie Żydów o mord rytualny, interpretowane w kontekście reformacyjnych sporów o eucharystię, Sochaczew 1558, zob. np. ks. S. Śleszkowski, Odkrycie zdrad złośliwych..., Braniewo 1621; Z. Guldon, J. Wijaczka, Procesy o mordy rytualne w Polsce w XVI-XVIII wieku, Kielce 1995, s. 86.

7 Np. we współczesnej propagandzie prawosławnej związanej z kultem Dzieciątka Gabriel, zob. J. TokarskaBakir, Raport z badań podlaskich 2007, „Societas/Communitas: Polityki pamięci”, ISNS UW, Warszawa 2009, s. 35-94.

8 Motyw folklorystyczny: w indeksie Thompsona motyw V361; S. Thompson, Motif-Index of Folk-Literature. A Classification of Narrative Elements in Folk-Tales, Ballads, Myths, Fables, Mediaeval Romances, Exempla, Fabliau, Jest-Books, and Local Legends, "FF Communications No. 106», Helsinki 1932. 
gdzie „szkodzeniem“ jest porwanie dziecka na macę, „walka” dotyczy zadawania mu mąk przez Antagonistę, tudzież prób wyciszenia zbrodni, która w funkcji "zwycięstwo"/ zdemaskowanie mimo wszystko wychodzi na jaw i prowadzi do "ukarania" Żydów9.

Od przełomu wieku XVI i XVII religijna figura Krwiopijcy w literaturze plebejskiej i kościelnej antyżydowskiej obrastała w konteksty przenośne, związane z żydowską lichwą, psuciem chrześcijańskich obyczajów i rozpijaniem ludności przez żydowskich karczmarzy. Prawdziwy renesans przeżyła ona wraz z pojawieniem się tendencji asymilacyjnych w wieku XIX i antysemityzmu nowoczesnego. Wtargnięcie czynnika obcego do Ciała Społecznego sugerowały teraz coraz bardziej volkistowskie obrazy Żydów, dokonujących zamachu na wartości narodowe, przedstawiane w biologicznych kategoriach krzepy, zdrowia, „zacnej krwi“. Żydów porównywano do owadów i organizmów w sposób inwazyjny naruszających granice ciała: pcheł, wszy, pluskiew, a także do chorób roznoszonych przez te owady. Zdarzały się też inne warianty Krwiopijcy: Żyd-pasożyt, Żyd jako narośl i „zaraza” - „tyfus, cholera, dżuma“ czy "gangrena“10. Niepoślednią rolę w tym dyskursie odgrywała też rozpowszechniona przez romantyzm (Zygmunt Krasiński, Nie-Boska komedia) figura „przechrzty“ - antagonisty zamaskowanego ${ }^{11}$, który podstępnie dostaje się do Ciała Wspólnoty i zatruwa ją swoimi jadami².

Dopiero jednak w wieku XX, w okresie dwudziestolecia międzywojennego, dyskurs o Krwiopijcy, w którym incydentalnie pojawiały się dotąd elementy narodowe został de facto zastąpiony dyskursem n a r o d o w y m. Odtąd Krwiopijca, który bywał Żydem (jednak w pojedynczych przypadkach także husytą, protestantem czy unitą), ostatecznie przekształcił się Żyda Krwiopijcę. Identyfikacja była tak dokładna, że pierwszy sygnował dru-

\section{- ・ ・}

9 Zob. LK 328

10 Zob. tekst z kwartalnika „Rodzina Polska“, lipiec 1926, Księża Pallotyni, Wadowice-Kraków "Na Kopcu“: „[Żyd] porzucił własną ziemię, jął się włóczęgostwa z postanowieniem życia na cudzy koszt. Jak wesz, pluskwa, szarańcza, zarazek tyfusu, bakcyl cholery i dżumy... Zażądał równouprawnienia i «tolerancji «, [czyli] poddania się świata chrześcijańskiego żydowskiej nawale, i abdykuj, chrześcijaninie - wyrzekaj się wiary, narodowości, ziemi, nieba - oddaj, coś nagromadził - spal Pismo święte, obal Papiestwo, przebuduj kościoły na synagogi, zapuść pejsy, włóż «cecele« i pójdź na żydowskiego parobka... całe legje zdrajców własnego kraju, duszami i mózgiem zaprzedanych judaizmowi, dziesiątkami lat popełniają nieustającą zbrodnię zaprzaństwa narodowego... Całe to zbiegowisko opryszków najgorszego gatunku wyciska na masach narodowych odpowiednie piętno..." Dziękuję Tadeuszowi Markielowi za kopię tego tekstu. Wywód w „Kwartalniku" spowinowacony jest pod względem stylistycznym i argumentacyjnym z publikacjami ks. Józefa Kruszyńskiego, o których piszę w sekcji Dyskurs elitarny: duchowni i hierarchowie.

11 Zob. np. S. Didier, Rola neofitów w dziejach Polski, Warszawa 1934; S. Tworkowski, Polska bez Żydów Warszawa 1939, rozdz. VI: „Najniebezpieczniejszym gatunkiem Żyda jest Żyd wychrzczony. Chrzest bowiem ułatwia takiemu Żydowi przenikanie do społeczeństwa. Otwiera mu drogę do stanowisk, urzędów, ułatwia przenikanie do ośrodków kulturalnych, jednym słowem Żyd, grając obłudną rolę chrześcijanina, usypia czujność społeczeństwa i łatwiej przeprowadza swoje cele“. Obszerna analiza figury przechrzty zob. M. Janion, Mit założycielski polskiego antysemityzmu, w: tejże: Bohater spisek, śmierć. Wykłady żydowskie, Warszawa, 2009, s. 77-113.

12 Sam obraz „wroga wewnętrznego“ jest w Polsce znacznie starszy, wczesnobarokowy. Odnaleźć go można już w dziele księdza Przecława Mojeckiego, Zydowskie okrućieństwá, mordy y zabobony, Kraków 1598. Odnotowuje go także Bazyli Wąglicki (Vaglicius), Swawola wyuzdána Zydowska, b.m.w., 1631, s. 3: „Zásta tem ia, przyiáchawszy, tylko ieden dom Zydowski w Oleszycách, y ten bárzo ćichy; teraz iest iuż czternaśćie y więcey gospodarzow, á dźieck iák száráńczy w Egyptćie, ktorzy w nárożnych y inszych przednieyszych domách rynkowych mieszkánia sobie u Mieszczan ponáymowawszy, iák brzydcy páiąkowie ná ubogie pczołki W.[aszej] M.[iłości] lichwiárskie swoie śiatki rozsádźili, áby ie, zdrádliwą dogody uczynnośćią uwikłane, wyssáli y zniszczyli; á potym bez targu y zapłáty pracą y dobrá ich pośiadáli". Siedemnastowieczna polska literatura sowizdrzalska porównywała Żydów do „czerwia w zrębie pięknym, mola w szatach kosztownych" (Jan Jurkowski, Poselstwo z Dzikich Pól, w: tegoż, Utwory, s. 266, za: U. Augustyniak, Koncepcje narodu i społeczeństwa $w$ literaturze plebejskiej od końca XVI do końca XVII wieku, Warszawa 1989, s. 62). Pisarze patrycjuszowscy tego okresu przedstawiali Żydów jako pijawki, wszy i mole i zapytywali, co robi w Polsce „ów chytry ród węży,/ [co] nieprawe zyski najłapczywiej garnie/ i srogą lichwą ubogich ciemięży”, Sebastian Fabian Klonowic, Roksolania, przeł. L. Kondratowicz (W. Syrokomla), Wilno 1851, s. 78-9, za: Augustyniak, dz. cyt., s. 69. Zob. też dyskusja Augustyniak z tezą Janusza Tazbira, że w dobie baroku "nie znano jeszcze pojęcia wroga wewnętrznego", tamże, s. 55-56. 
giego. Widać ją w tekście z roku 1926, pochodzącym z miesięcznika „Rodzina Polska“13, wydawanego przez księży pallotynów w Wadowicach. Czytamy w nim m.in.:

„Jeśli Żyd jest wampirem - na określenie goja w służbie Żyda słownictwo nie ma wyrazu"14.

Wzmiance o żydowskim Krwiopijcy towarzyszy tu zapowiedź większego skandalu: jest nim goj, który łamie zakaz kontaktowania się z Żydami ${ }^{15}$. Od tej transgresji rozpoczynają się wszystkie warianty legendy o krwi: profanacja hostii lub porwanie dziecka "na macę" jest karą za złamanie tego zakazu.

Artykut, z którego pochodzi cytat, jest typowy dla polskiej odmiany antysemityzmu, myślowo niesamodzielnej, z reguły przywołującej zachodnioeuropejskie przykłady. Autor posługuje się formą wykładu, który poprze z wypisy z klasyków wprowadza prowincjonalnego czytelnika w świat europejskiej myśli antysemickiej. Pojawiają się w nim przytoczenia z Diodora, Tacyta, Lutra, Woltera, Goethego, Napoleona I, Wiktora Hugo, Schopenhauera, Franciszka Lista, Duehringa, Bismarcka ${ }^{16}$. Drugą część artykułu wypełnia omówienie Protokołów mędrców Syjonu. Poniżej zestawiam wszystkie metaforyczne określenia Żydów z omawianych tekstów.

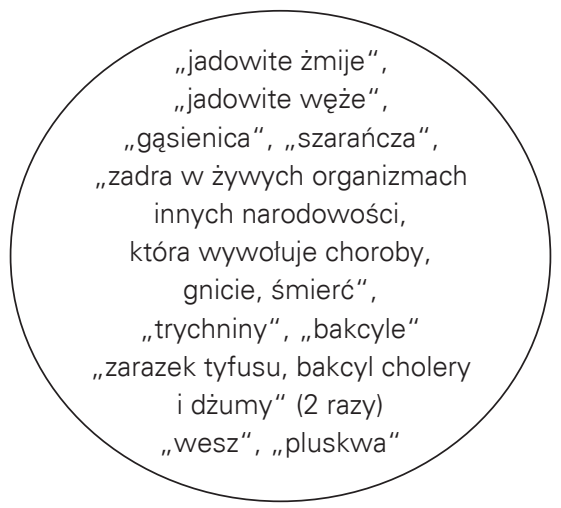

Ryc. 1. Krwiopijca narodowy, na podstawie miesięcznika „Rodzina Polska" księży pallotynów w Wadowicach, 1926.

Właściwie wszystkie metafory w tekście (poza „ludożercą“) koncentrują się na opisie zakazanego ruchu w obrębie strzeżonej granicy "wnętrze“/ zewnętrze”, a więc spełniają minimalną definicję, jaką przyporządkowaliśmy figurze Krwiopijcy.

Trzecią po dyskursie religijnym i narodowym odmianą figury Krwiopijcy jest wariant, jaki przybrała ona w marksistowskich ideologiach I e w i c o w y c h ${ }^{17}$. Przykład, do którego się ograniczę, pochodzi z pieśni w języku żydowskim i rosyjskim, zatytułowanej Vam-

\section{-....}

13 F. Adamski, The Jewish Question in Polish Religious Periodicals in the Second Republic: The Case of "Przegląd Katolicki”, "Polin" 1994, t. 8, s. 129-145; A. Landau-Czajka, The Image of the Jew in the Catholic Press during the Second Republic, "Polin” 1994, t. 8, s. 146-175; S.C. Napiórkowski (red.), A bliźniego swego... Materiaty z sympozjum Św. Maksymilian Maria Kolbe - Żydzi - Masoni", Lublin 1993; P. Forecki, Chrześcijańskie motywacje antysemityzmu na łamach „Rycerza Niepokalanej”, [w:] Na obrzeżach polityki, M. Kosman (red.), Poznań 2002, t. 1, s. 113-129; P. Forecki, Polityczny charakter treści antysemickich na łamach "Rycerza Niepokalanej", [w:] Na obrzeżach polityki, M. Kosman (red.), Poznań 2002, t. 2, s. 53-69.

14 "Na ten temat zob. w sekcji Żotnierze i oficerowie podziemia, o „pachołkach żydowskich”.

15 Zob. LK 389-392.

16 Jego nazwisko, ostatnie na liście cytatów, ustanawia terminus post quem, pozwalający datować źródło, z którego korzystał ksiądz pallotyn.

17 Obszernie na temat dynamiki antysemityzmu lewicowego: A. Lustiger, Czerwona Księga. Stalin i Żydzi. Tragiczna historia Żydowskiego Komitetu Antyfaszystowskiego i radzieckich Żydów, przeł. E. Kazimierczak, W. Leder, Warszawa 2004. Antysemickie fragmenty pism Karola Marksa przytacza np. Paul Johnson, Historia Żydów, Kraków 1993, s. 373. 
pirn (,Wampiry') z roku 1930, zapisanej przez M. Bieregowskiego w Humaniu na Ukrainie. „Krwiopijcy wyzyskiwacze", o których mówi się w tej pieśni, to kapitaliści, w tym także żydowscy. Jako refleks swoich czasów figura ta pojawia się w tytule Pluskwy (1929) Włodzimierza Majakowskiego. Podobnie jak w metaforze religijnej, Krwiopijca może (choć nie musi) być Żydem, podobnie też nie każdy Żyd jest Krwiopijcą. We współczesnych interpretacjach powyższą kategorię traktuje się jako tzw. metaforę martwą. Stanowi ona przetrwalnik, którego uśpione znaczenie łatwo jest obudzić ${ }^{18}$.

Omówioną figurę w trzech jej wcieleniach ukazuje poniższa tabela.

\begin{tabular}{|c|c|c|c|}
\hline Typ dyskursu & $\begin{array}{c}\text { Określenie agresora } \\
\text { i znaczenie jego działania }\end{array}$ & Określenie ofiary & Opis agresji \\
\hline Religijny & $\begin{array}{l}\text { określenie dosłowne: } \\
\text { krwiopijca" (np. Żyd) }\end{array}$ & $\begin{array}{l}\text { "dziecko } \\
\text { chrześcijańskie", } \\
\text { dziecko katolickie" }\end{array}$ & $\begin{array}{l}\text { porywanie dzieci "na krew", } \\
\text { "na mace", "kłucie" w celu } \\
\text { wydobycia krwi }\end{array}$ \\
\hline Narodowy & $\begin{array}{l}\text { określenia metaforyczne: } \\
\text { "Żyd-krwiopijca", } \\
\text { "wampir" }\end{array}$ & "Polacy", "Naród” & $\begin{array}{l}\text { "wesz", „pluskwa”, } \\
\text { "Szarańcza", ,zarazek } \\
\text { tyfusu”, , bakcyl cholery } \\
\text { i dżumy" }\end{array}$ \\
\hline Lewicowy & $\begin{array}{l}\text { określenia metaforyczne: } \\
\text { "wampir", ",krwiopijca" } \\
\text { (np. żydowski kapitalista), } \\
\text { "wyzyskiwacz" }\end{array}$ & „klasa robotnicza“ & wyzysk ekonomiczny \\
\hline
\end{tabular}

Ryc. 2. Figura Krwiopijcy w dyskursie religijnym, narodowym i lewicowym.

\section{POLSKA 1945-1946: "KRWIOPIJCA" JAKO ORGANIZATOR ROZBITEJ WSPÓLNOTY}

Niechęć do „Żyda Krwiopijcy“, figury zrozumiałej dla wszystkich adresatów: katolików, narodowców i komunistów stała się po drugiej wojnie światowej spoiwem polskiej wspólnoty wyobrażonej (Benedict Anderson). Była ona jedną z nielicznych emocji, jaka w nowych warunkach i na gruncie rozmaicie wykładanego patriotyzmu mogła połączyć katolika, narodowca z NSZ, ideowego żołnierza AK i GL-owca. Nowością było to, że szybko stała się czytelna także dla części komunistów, którzy frazeologię narodową połączyli z lewicową krytyką „kapitału“.

Proces ten następował dzięki temu, że w omawianym okresie metafora Krwiopijcy podlegała gwałtownemu udosłownieniu (symbolic equation w terminologii Hanny Segal, zob. dalej) któremu sprzyjały dwie migracje znaczeń:

- po pierwsze, od końca wieku XIX trwało przesuwanie się religijnych znaczeń figury w kierunku znaczeń narodowych;

\section{-...・}

18 Zob. manipulacja lewicową figurą Krwiopijcy po pogromie kieleckim przez władze komunistyczne: „Dnia 11 lipca odbyła się wspólna narada PPR i PPS w Kielcach. Na tej naradzie postanowiono rozpocząć aresztowania wśród elementów pasożytniczych oraz zamykanie domów rozrywkowych, a opróżnione lokale oddać robotnikom. Nasi i PPS wszyscy agitatorzy wskazali na krzywdzicieli ludu w postaci restauratorów i społeczników [?]. Na wszystkich masówkach lud swoje oburzenie przestawił z Żydów na elementy pasożytnicze w ogóle. Akcja ta miała duże powodzenie, bo odpowiadała rozpalonym nastrojom niezadowolonych. Powstato przekonanie, że wreszcie i Partia szuka i karze krzywdzicieli ludu", Sprawozdanie instruktorów KC PPR z pobytu w województwie kieleckim od 4 do 15 lipca 1946, za: Antyżydowskie wydarzenia kieleckie 4 lipca 1946 roku. Dokumenty i materiaty, tom I: oprac. Stanisław Meducki i Zenon Wrona, Kielce 1992; tom II: oprac. Stanisław Meducki, Kieleckie Towarzystwo Naukowe, 1994, s. 142 (dalej resp.: Meducki I i II). Szerzej na ten temat dalej w sekcji: Żydzi w dyskursie urzędowym i lewicowym. 
- po drugie, w latach po II wojnie, między innymi pod wpływem lansowanej przez stalinizm koncepcji państwa narodowego ${ }^{19}$, także lewicowe pole semantyczne figury zaczęto gwałtownie dryfować w rejon asocjacji narodowych, uwydatniając postać Żyda, który wcześniej pojawiał się w tle.

Krwiopijca: asocjacje religijne
$\Downarrow$
Krwiopijca: asocjacje narodowe
$\Downarrow$
Krwiopijca: asocjacje lewicowe

Ryc. 3. Ciążenie pola semantycznego Krwiopijcy ku kategoriom narodowym, 1945/1946.

Te dwa ruchy znaczeń zilustruję w dalszej części analizując:

1. dyskurs popularny, a w nim listy ze wzmiankami o mordzie rytualnym, zatrzymane przez cenzurę wojskową w roku 1945;

2. dyskurs elitarny, a w nim wzmianki o mordzie rytualnym w wypowiedziach polskiego kleru katolickiego i oficerów podziemia;

3. dyskurs oficjalny i półoficjalny, a w nim sprawozdania starostów i wojewodów dotyczące Żydów z lat 1945/1946 i powracające w nim wzmianki o Żydach-pasożytach i wyzyskiwaczach, "kapitalistycznych krwiopijcach".

\section{DYSKURS POPULARNY \\ Listy przechwycone przez cenzure}

O kształcie pogłoski o krwi, kursującej po Polsce w roku 1945 informują listy przechwycone przez Cenzurę Wojenną w sierpniu roku $1945^{20}$. Jak wynika z ich interpunkcji (a raczej jej braku), stylistyki, ortografii i leksyki listów, ich autorami byli ludzie słabo wykształceni.

W legendach o krwi ofiare mordu rytualnego zawsze określano mianem „dziecka chrześcijańskiego" lub "katolickiego". Analiza źródeł dowodzi, że w języku ludności etnicznie polskiej (w odróżnieniu od żydowskiej ${ }^{21}$ ) sformułowanie to stopniowo zanika. W cytowanych listach jego zamiennikiem stał się frazeologizm "dziecko polskie". Kursy-

\section{$\cdots \cdot \cdots$}

19 S. Ossowski, Na tle wydarzeń kieleckich, „Kuźnica”, nr 38: 1946, przedruk w: „Kultura i Społeczeństwo“, nr 1: 1987, s. 54: „Na parę dni przed wydarzeniami kieleckimi ukazał się w «Myśli Współczesnej« [nr 2, lipiec 1946, s. 202] artykut E.St. Rapaporta pt. Polska jako państwo jednonarodowe. Od razu we wstępnych uwagach autor wyraża pogląd, że «odtąd, w chwili ukształtowania się stosunków międzynarodowych i międzypaństwowych po II wojnie światowej, pojęcia «Polak« i «Obywatel Polski« i dla nas na wewnątrz i dla obcego na zewnątrz stać się, gdy chodzi o Polaka na stale w kraju zamieszkałego, bezspornymi synonimami«. (...) «Na razie, mówi dalej autor - dbać musimy o jedno, aby wszelkimi sposobami jak najprędzej doprowadzić stan faktyczny jednonarodowości w Państwie Polskim do możliwego maximum natężenia ". Zob. też rok wcześniej, Stanisław Przygórski, Przeciw potędze ciemnoty (polemika z tekstem Mieczysława Jastruna, Potęga ciemnoty, reakcją na pogrom krakowski), "Odrodzenie” nr 34: 22/07/1945: "Żyd w Polsce demokratycznej posiadt równe, należne mu prawa i z praw tych słusznie korzysta. Jest towarzyszem doli i niedoli, jest kolegą przy wspólnym warsztacie pracy, jest współtwórca nowej Polski, w której ustroju nie ma miejsca na zagadnienia mniejszościowe, sztucznie konstruowane przez dętologię profaszystowską", za: Meducki II 49. Zob. także: J. Kwiek, Żydzi, Łemkowie, Stowacy w województwie krakowskim w latach 19451949/50, Kraków 2002, s. 5-6. Także: K. Kersten, Polska - państwo narodowe. Dylematy i rzeczywistość, w: Narody. Jak powstawały i jak wybijały się na niepodległość, Warszawa 1989, s. 476.

20 Specjalne doniesienie dotyczące zajść antyżydowskich w Krakowie, AIPN MBP 3378, cyt. za: M. Zaremba, Mit mordu rytualnego w powojennej Polsce. Archeologia i hipotezy, "Kultura i Społeczeństwo", nr 2: 2007 (dalej: Zaremba), s. 104-105.

21 Zob. np. relacja Józefa Wulfa: „Motłoch opowiadał, że Żydzi zamordowali dziecko chrześcijańskie...”, J. Wulf, Dialog polsko-żydowski, "Wiadomości”, nr 12: 1965, cyt. za: Kwiek, Żydzi, Łemkowie, Słowacy, dz. cyt., s. 63. Zob. też K. Kaczmarski, Pogrom którego nie było. Rzeszów 11-12 czerwca 1945. Fakty, hipotezy, dokumenty (dalej: Kaczm.), Rzeszów 2008, s. 92, 97. 
wą podkreślam leksykę religijnego dyskursu o krwi, rozspacjowaniem zaś „zmodernizowaną" leksykę narodową.

List 1 z Krakowa:

U nas w mieście są potyczki z żydami [aluzje do pogromu krakowskiego], bo wyobraź sobie, że żydzi posunęli się do tego stopnia, że zabijają dzieci pols kie na krew, a brali ich podstępem, aby im odnieśli walizki do bóżnicy. Płacili im po 100 zł, a wiesz, że dzieci są łakome na pieniądze, zwłaszcza chłopcy. Okazało się, że jeden był morowy dochodząc do bóżnicy usłyszał płacz dzieci i nie czekając na resztę z piątki zwiał i dał znać na milicję. Milicja została kilka trupów w piwnicy w bożnicy. Momentalnie rozniosło się po catym mieście i Polacy, gdzie spotkali żyda to prali a na tandecie porozbijali im kramy. Nawet była straszna strzelanina i było kilka ofiar dokładnie nie wiem kto.

List 2 z Brzeska Nowego k. Krakowa:

Opisze ci jeszcze jeden wypadek w Krakowie, który rozegrał się w dzielnicy, gdzie obecnie mieszkam [Kazimierz]. Od jakiegoś czasu ginęły dzieci aż 11.8 wyrwał się z rąk żydów 14-letni chłopiec, który miał podcięte żyły u ręki. Żydzi spuszczali krew z rąk i nóg katolickim dzieciom i na co? To okaże się w tych dniach. Były takie wypadki w Rzeszowie [pogrom rzeszowski], ale prasa sprostowała, że to niemożliwe. Więc teraz wykryło się, że to jest święta prawda. Ludność rzuciła się i zdemolowała synagogę a na żydach spotkanych na ulicy robili samosądy. Żydzi z bronią w ręku bronili się, ale w tą sprawę weszło wojsko to i była haratanina. Teraz już nikt nie zaprzeczy, że jewreje tych rzeczy nie robili, nawet prasa.

List 3 z Kralki (gm. Niedźwiedź k. Krakowa):

...w tych dniach takie mamy nowiny tj. w Krakowie - żydzi zamordowali kilkana ścioro polskich dzieci. Znaleziono beczki krwi. Sprawą zajęło się wojsko Polskie i Sowieckie.

List 4 z Krakowa:

W Krakowie są rozruchy z żydami, że żydzi łapią małe dzieci i ściągają z nich krew dla żydów, którzy powracają z obozów.

List 5 z Krakowa:

Może dowiedzieliście się z gazet co się działo w Krakowie 11/8/45 r. Do czego żydzi hitlerowscy dążyli, co zrobli. Są już pochwyceni i ani śladu z nich nie zostało.

List 6 z Okocimia:

Donosze ci przygody w Krakowie, żydzi wymęczyli 17-ro polskich dzieci to wszystko się wydało, bo dziewczynka 12-letnia uciekła z połamanymi rękami i ustami i w tem krzyk i bałagan straszny. Żydostwo zaczęto strzelać do polskich żołnier z y z okien i ulicą przejść nie było można. Zostało zabitych kilku p o l s k i c h żołnierzy.

List 7 (podane zostało tylko nazwisko żołnierza i numer jego jednostki):

Znowu w Krakowie żydzi dużo polskich dzieci zabili i piliz nich krew. Polscy żołnierze dużo żydów pozabijali, no ich NKWD ochronito.

Cytowane wypowiedzi możemy uporządkować - wedle dostępnych cech dystynktywnych - dzieląc je na dwie kategorie: religijne i narodowe. Widać przesuwa n i e się pola dyskursu z rejonów stricte religijnych w rejon asocjacji narodowych. 
Do grupy wypowiedzi religijnych, operujących dystynkcją "Żydzi“/"katolicy", należy tylko list 2. Pozostałe listy wpisują konflikt w kategorie narodowe:

- 1: „żydzi“/ "dzieci polskie“

- 3: "żydzi“/"dzieci polskie"; „„żydzi“/ "wojsko Polskie i Sowieckie“

- 6: „ż̇ydzi“/,polskie dzieci”; „żydostwo“/ „polscy żołnierze” (2 razy)

- 7: „żydzi“/, polskie dzieci”; "żydzi“/ "polscy żołnierze”

albo też określenie ofiar („małe dzieci“) pozostawiają bez bliższych określeń narodowości (list 4 i 5). Bez zmian pozostają inne znane z dyskursu religijnego elementy leksykalne legendy o krwi, takie jak „na krew”/,spuszczanie krwi“/,beczki z krwią“/,podcięte żyły u ręki"/,żydzi wymęczyli“/ "piwnica w bożnicy".

Na uwage zasługuje motyw ze msty-kary, obecny we wszystkich listach poza jednym:

- 1: [Polacy] „prali żyda“ i „porozbijali żydom kramy“,

- 2: "Żydzi bronili się", „w sprawę weszło wojsko" (bez określenia, jakie),

- 3: "sprawą zajęło się wojsko Polskie i Sowieckie",

- 5: "są już pochwyceni i śladu z nich nie zostało",

- 6: aluzja do zbrojnej obrony Żydów przed atakiem „żołnierzy polskich“,

- 7: „polscy żołnierze dużo żydów pozabijali, no ich NKWD ochroniło“.

W schemacie legendy o krwi motyw zemsty-kary na Żydach zwieńczał każdą narrację, którą można uznać za przynależną do kategorii blood libel. Wspominałam, że ścisły schemat legendy o krwi można sprowadzić do sekwencji czterech funkcji fabularnych:

szkodzenie - walka - zwycięstwo / zdemaskowanie Antagonisty - ukaranie.

Wszystkie fabuły, o których mowa w listach, zbudowane są, po pierwsze, na charakterystycznej dla legend o krwi wierze w porywanie dzieci "na krew“ przez Żydów (tzw. truth claims narracji), po drugie zaś opierają się na schemacie fabularnym legendy (blood libel legend scheme) albo też na jego oczekiwaniu²2.

Oczekiwanie, że sprawy potoczą się zgodnie ze schematem legendy widać wyraźnie w liście 1, gdzie dodatkowo pojawiają się takie charakterystyczne szczegóły schematu jak „podstępne namowy Antagonisty“ i „zdemaskowanie Antagonisty". Pierwszy znamy z popularnej baśni o Babie Jadze, gdzie występuje nęcenie dzieci pierniczkami²3. W przekazanej przez księdza Piotra Skargę narracji o Szymonie z Trydentu († 1475) brzmi to następująco:

„podał mu [Żyd Tobiasz] pieniędzy i jagód i innych dziecinnych łaskotek iż milczało dziecię, aż przyszedł do drzwi Samuela i tam je wepchnął"24.

W jednym z cytowanych listów (1) funkcję tę wyrażają zdania:

„[Żydzi] brali ich [tzn. dzieci] podstępem, aby im odnieśli walizki do bóżnicy. Płacili im po 100 zł, a wiesz, że dzieci są łakome na pieniądze, zwłaszcza chłopcy".

Z kolei funkcja „zdemaskowanie Antagonisty", w legendach o krwi występująca jako cudowne światła, znaki, „krwawiąca ściana“25 lub skarga wydobywająca się z piwnicy

22 Zaznacza się to w uldze, jaką wyraża autor listu 2: "więc teraz wykryło się, że jest to święta prawda”, "teraz już nikt nie zaprzeczy, że jewreje tych rzeczy nie robili, nawet prasa".

23 Alina Cała przytacza kontaminację tych dwóch baśni: „najpierw w piwnicy [go] trzymali, orzechami karmili, a potem wsadzali do beczki i katowali“" A. Cała, Wizerunek Żyda w polskiej kulturze ludowej, Warszawa 2005, s. 48.

24 Piotr Skarga, Żywoty Swiętych Starego y Nowego Zakonu, na każdy dzień przez cały rok, drukarnia A. Piotrkowczyka, Kraków 1610, s. 262, na dzień 30 marca (24 marca): Męczeństwo pacholęcia Szymona Trydenckiego od Żydów umęczonego pisane od Doktora Jana Macieja Tybaryna do Senatu Brygji. Funkcja u Proppa oznaczona symbolem $\eta^{1}$.

25 Zob. w mojej książce: LK narracja 40M Rudolfa ze Schlettstadt: gdy Żydzi przebijali porwaną hostoę, „rzekłbyś, mały chłopczyk wydał żałosny jęk". Powtarzający się głos ten ściąga na miejsce chrześcijan, którzy odkrywają 
wyraża się płaczem, który usłyszał "morowy" chłopiec, który zbiegł spod synagogi i zawiadomił milicję. O chłopcu mniej zręcznym, "14-letnim z pociętymi żyłami u ręki”, mowa także W liście 2. W liście 6 zamiast chłopca mamy jeszcze „dziewczynkę 12-letnią, [która] uciekła z połamanymi rękami i ustami i w tem [w] krzyk".

W religijnych legendach o krwi każdy z adwersarzy, porwany Bohater i porywający go Antagonista, mają pomocników. W sensie zbiorowym stanowią ich kolektywy "Żydów" i „chrześcijan", te zaś wyemanowują z siebie dodatkowo pomocników indywidualnych.

W rozpatrywanych listach też tacy występują:

- Pomocnikiem Antagonisty (tj. Żydów) jest NKWD (list 6),

- Pomocnikiem Bohatera (tj. „dzieci polskich“) jest „wojsko polskie“ (listy 3, 6, 7) i "milicja" (list 1).

Listy 2, 3, 6 i 7 afirmują „w o j s k o" jako kolektywne ramię ludu, wymierzające sprawiedliwość. Odzwierciedla to nastroje społeczne czasów tużpowojennych, w których nawet w "Rycerzu Niepokalanej” w artykule zatytułowanym Wojsko polskie perłą wśród innych wojsk! czytamy, że wojsko to jest "nasze” i „wytęsknione"26. W listach zarysowuje się już jednak dystynkcja „wojsko polskie“/ "wojsko sowieckie“(list 3), która pogłębi się w podziemnych meldunkach i odezwach, przytaczanych w kolejnej sekcji. Zapowiada ją opozycja „polscy żołnierze“/ „NKWD” w liście 7.

W liście 5 pojawia się tzw. morfologiczny wariant legendy o krwi27, stanowiący modernizację klasycznej postaci legendy, w której chodzi o dodawanie krwi dzieci do macy pieczonej na Święto Przaśników. Magiczna krew „dzieci chrześcijańskich" zostaje tu odczarowana, to jest zmedykalizowana i przedstawiona w postaci "transfuzji”, do czego być może przyczyniły się plotki o praktycznych zastosowaniach odkryć Ludwika Hirszfelda, które krążyły w latach tużpowojennych ${ }^{28}$. W zapiskach z roku 1946 Hugo Steinhaus wspomina, że od znajomego profesora powracającego z Krakowa słyszał, iż:

„"część tzw. inteligencji wierzy w ulepszony mord rytualny, którym tłumaczy wypadki kieleckie; jak wiadomo transfuzja (wynalazek Żyda Hirszfelda) krwi dziecięcej potrzebna jest do ratowania wycieńczonych Żydów z Rosji“"29.

Wariant morfologiczny legendy wydaje się konsekwencją zastąpienia dyskursu religijnego dyskursem narodowym. Podobnie jak tzw. wa ri a n t k i e tb a s i a n y ${ }^{30}$, rozkwitt on w tużpowojennych czasach niedostatku i głodu.

profanacje sakramentu. Motyw krawawiącej ściany na obrazie Paolo Ucello, predella ołtarza bractwa Corpus Christi, Galleria Nazionale della Marche, Palazzo Ducale, Urbino. Zob. też S. Greenblatt, Poetyka kulturowa. Pisma wybrane, K. Kujawińska Courtney [red. i wstęp], Kraków 2006, wkładka barwna po s. 306 i 307-330. "Rycerz Niepokalanej", nr 1: 1946, s. 10, za: Zaremba 106

27 Zob. LK 446.

28 Ludwik Hirszfeld (1984-1954), lekarz, mikrobiolog, immunolog, dyrektor Państwego Instytutu Higieny w Warszawie. W latach 1907-1911 pracował w Instytucie Badania Raka w Heidelbergu, gdzie wraz z niemieckim lekarzem E. van Dungernem stworzył podstawy nauki o grupach krwi (odkrył mechanizmy dziedziczenia grup krwi) i wprowadzit ich oznaczanie.

29 H. Steinhaus, Wspomnienia i zapiski, Londyn 1992, s. 354.

30 W dzień pogromu w Kielcach rozpuszczono pogłoskę, iż zaginął chłopiec, który potem odnalazł się w Ostrowie Wielkopolskim. „Chłopca tego miał rzekomo zamordować jakiś ukrainiec i mięso miał wywieźć czy też przerobić na kietbasy. Przy jednej z ulic zaczęły się gromadzić tłumy ludzi (...). Pogtoski stawały się coraz fantastyczniejsze, mianowicie że tych chłopcow było 4, 8, a nawet 24. Jedna nieujęta i niesprawdzona kobieta opowiadała, że widziała 14 główek dziecięcych i że mięso ukraińcy, względnie sowieci wywieźli na kiełbasy, a krew piją Żydzi", Sprawozdanie grupy trzech towarzyszy wysłanych przez Komitet Wojewódzki do Kalisza 10/07/ dla przeciwdziałania ewentualnym wystapieniom antysemickim, AAN, Bolesław Bierut - archiwum, 254/II-6, k. 77, za: Zaremba 118. Także „Dziennik Powszechny”, 22/03/1945 (gazeta radomsko-kielecka), Plotki o kietbasach z miessa ludzkiego, za: Zaremba 109. Inne świadectwa pochodzą z końca sierpnia 1946 roku z Przemyśla, gdzie milicja zanotowala, że brat pewnej dziewczynki donosił, iż „żydzi porwali ją na mięso, a on za to będzie żydów mordowat", Zaremba 118. Zob. też AAN, KC PPR, 295/NII-53, k. 35, za: L. Olejnik, Polityka narodowościowa Polski w latach 1944-1960, Łódź 2003 (dalej: Olejnik), s. 388. 
Odnotujmy w listach jeszcze jeden wątek wędrowny (Wandersagen): w liście 6 wspomina się o "Żydach, strzelających z okien do przechodzących polskich żołnierzy". Historia ta, w której strzelanie bywa zastępowane polewaniem wrzątkiem lub gorącym octem, w Polsce krąży co najmniej od roku 1939. Ilustruję ją w przypisie ${ }^{31}$. Topos będzie powracał w uzasadnieniach pogromów krakowskiego i kieleckiego, a także w tzw. akcji kolejowejpolowaniu na Żydów w pociągach w latach 1945-1946.

\section{DYSKURS ELITARNY}

Duchowni i hierarchowie

O tym, że wiarę w realność mordów krwi podzielali duchowni niżsi rangą2 ${ }^{32}$ dowiadujemy się z raportu księdza kanonika Romana Zelka, proboszcza parafii katedralnej w Kielcach, dla Kurii Diecezjalnej dotyczącego pogromu w dniu 4 lipca 1946 roku. Czytamy w nim m.in.:

„Błaszczyk Henryk, syn Walentego, lat 9, zamieszkały przy ojcu w Kielcach, ul. Podwalna 6, dnia 1 lipca został około 11 rano wynajęty przez jednego pana do odniesienia walizki do domu przy ulicy Planty nr 7, w którym mieszkańcami byli wyłącznie Żydzi. Po przyjściu do tego domu wspomniany chłopiec dostał jakiegoś napoju, po czym zasnął i obudził się 3 lipca nad wieczorem w piwnicy. Przy pomocy bawiących się przed domem dzieci żydowskich wydostał się z piwnicy i wrócit do ojca" ${ }^{3}$.

Cytowana historia to typowy początek legendy o krwi, nie różniący się od relacjonowanej w omawianych wcześniej listach. Dowiadujemy się, że Henio Błaszczyk miał tyle samo szczęścia co ów „morowy chłopiec” z listu 1, który uciekł Żydom sprzed nosa, za to więcej niż dzieci, które uciekły poranione (listy 2 i 6). Powtarza się tu wątek kuszenia za pomocą walizki (co należy do funkcji „podstępne namowy Antagonisty“), dodatkowo podkreślony przez figurę napoju magicznego, wywołującego dwudniowy sen chłopca.

Na pytanie, czy w latach tużpowojennych w to, że Żydzi mordują dla krwi, wierzyli wysocy hierarchowie kościelni, odpowiemy w trybie anachronicznym, porównując dwie wypowiedzi biskupów. Pierwszą jest prywatny list biskupa sandomierskiego Wacława Świerzawskiego z roku 199834, odpowiadający na pisemne zapytanie o cel eksponowania w katedrze sandomierskiej obrazów przedstawiających "żydowski mord rytualny". Stwierdzając, że "jest wśród badaczy tego problemu hipoteza, że w judaizmie istniała sekta, której wyznawcy w oparciu o nauke Talmudu dopuszczali się zarzucanejim zbrodni mordu rytualnego“, biskup sandomierski pyta: „czy kiedykolwiek zostanie ten

31 Zob. M. Turek, Życie i zagłada Tykocina w czasie okupacji hitlerowskiej, AŻıH 301/1971. Autor opisuje krążące w roku 1939 "dzikie pogłoski według starej treści, że Żydzi w Grodnie i in. miejscowościach oblewali wrzątkiem głowy żołnierzy polskich". Zob. też świadectwo tzw. akcji kolejowej z 1948 (?) roku: „Już przy powrocie, po przejechaniu granicy na polską stronę, miejscowości nie pamiętam, w lesie zatrzymano nasz transport. Z początku nie wiedzieliśmy w jakim celu? Być może, by nas wybić? Podchodza do nas wojskowi, jeden taki porucznik, czy może podporucznik, dokładnie nie pamiętam, podszedł do naszego akurat wagonu i zapytat, czy są wśród nas Żydzi? Gdy ustyszal, że nie, wtedy dopiero zdjął czapkę i pokazuje głowę. Bo, mówi, gdyby oni, Żydzi, byli w osobnym wagonie, to my byśmy kazali odczepić ten ich wagon i byśmy ich wszystkich zniszczyli. Bo, mówi, prosze państwa, zobaczcie. Tu znowu zdjął czapkę. Jak myśmy byli w Gdansku i w 1939 r. szliśmy ulicami, to Żydzi z okien wylewali nam na głowy gorący ocet". Relacja Genowefy Małczyńskiej w: Jedwabne w oczach świadków. Relacji wysłuchał i do publikacji przygotował ks. Edward Marciniak, Wydawnictwo Duszpasterstwa Rolników, Włocławek 2001, s. 69. Zob. też Steinhaus, dz. cyt., s. 272.

32 Także członkowie bractw zakonnych mieli wierzyć w legendę o krwi, zob. Raport dekadowy za okres od 7 VII do 17 VII, MUBP w Częstochowie, AIPN w Katowicach, k. 203, w: Zaremba 127, przyp. 143.

33 Raport o zajściach kieleckich $w$ dn. 4/07/1946, sygnowany przez ks. Romana Zelka, 1946, Materiaty zarekwirowane przez UB podczas rewizji w Katedrze Kieleckiej w dn. 1/01/1952, za: Dzieje Żydów w Polsce, dz. cyt., s. 53-55

34 List biskupa z 6/04/1998 r., adresowany do prof. dr hab. Moniki Adamczyk-Garbowskiej, został mi uprzejmie udostępniony przez Adresatkę. 
problem wyjaśniony“, potem zaś dodaje: "z pewnością nie można całego narodu Żydowskiego oskarżać o takie zbrodnie". Biskup Świerzawski powtarza tu w gruncie rzeczy stanowisko sformułowane 17 lipca 1946 roku przez biskupa lubelskiego Stefana Wyszyńskiego, który opowiadał o "starych i nowych księgach żydowskich“, zgromadzonych jeszcze w procesie Bejlisa, „w których [to księgach] sprawa krwi nie jest jeszcze ostatecznie załatwiona" ${ }^{\text {". }}$.

Nieświadomie powtarza on jednak opinię dużo starszą, którą 152 lata wcześniej następująco sformułowano w „Przyjacielu Ludu“. Pewna kobieta, głodna i wielodzietna, zgodziła się oddać jedno ze swoich dzieci natarczywie proszącemu ją o to Żydowi. ( "Czyn, który tu opowiadam jest prawdziwy“ - zapewnia korespondent „Przyjaciela Ludu“.) Żyda widziano następnie, jak wchodzit „z wielkim koszem do miasta Dąbrowy [Tarnowskiej]. Dalej zginął ślad dziecka“. Matkę sądzono, wówczas wskazała na Żyda. Sąd uwolnił oboje od zarzutów.

„Ale wieść o spełnionej zbrodni przez całą żydowszczyznę wszerz i wzdłuż się rozległa. Między ludem naszym powszechnią jest wiara, że Żydzi potrzebują do pewnych obrządków krwi chrześcijańskiej".

\section{Dalszy ciąg cytatu z "Przyjaciela Ludu“:}

„W Ostrorogu na Wołyniu pokazują w katedrze beczkę wybitą gwoździami krwią zbroczonymi. Od kilku wieków przechowują ten dowód okropnego zabobonu wraz z opisem całego zdarzenia i aktami urzędowymi, opisującymi zbrodnię i winowajcow. Nie należy bynajmniej obwiniać religii żydowskiej o tak barbarzyńską zbrodnię, ale to pewna, że była między nimi jakaś sekta zagorzałych fanatyków, taknąca dzikich tych ofiar" ${ }^{\prime \prime} 6$.

Stanowisko, sformułowane przez korespondenta „Przyjaciela Ludu“ w roku rzezi galicyjskiej, a półtora wieku później powtórzone przez biskupa Świerzawskiego możemy nazwać „toposem sekty zagorzałych fanatyków“37. List bp. Świerzawskiego, a konsekwentnie to, co w roku 2005 można było usłyszeć od urzędników Kościoła katolickiego w Sandomierskiem ${ }^{38}$ zaświadcza o funkcjonalności tego motywu w światopoglądzie potocznym polskich katolików na prowincji.

Kwestia, czy powojenna hierarchia mogła dawać wiarę legendzie o krwi powracała też w debacie o książce Jana Grossa Strach. W kontekście formacji polskiego kleru, kształconego na dziełach ks. Piotra Skargij9 wydaje się ona bałamutna. Mając w pamięci fakt, że ostatnie wydanie Żywotów Świętych Skargi, zawierające pełny opis mąk św. Szymona

\section{......}

35 O wypowiedzi tej informują różne źródła, zob. np. Odpis sprawozdania z audiencji biskupa Stefana Wyszyńskiego ordynariusza lubelskiego delegacji Wojewódzkiego Komitetu Żydów w Lublinie z 10/10/1953, sygnowany przez M. Szyldkrauta i S. Słusznego (zgodność z oryginałem potwierdzona przez Grzegorza Smolara), za: Meducki II 116-117. Zob. też wcześniejsza o 7 lat notatka w: Sprawozdanie członków delegacji WKZ̈P w Lublinie z audiencji u bp. Stefana Wyszyńskiego, Lublin, 17/7/1946, cytowana przez Jana Żaryna; tegoż, Hierarchia Kościoła katolickiego wobec relacji polsko-żydowskich w latach 1945-1947, w: Wokót pogromu kieleckiego, Jan Żaryn, Łukasz Kamiński (red.), t. I, Kielce 2006, s. 96: „W dyskusji na temat podżegania motłochu, kłamliwa legenda o konieczności krwi chrześcijańskiej na mace, ks. biskup wyjaśnia, że jeszcze w procesie Bejlisa, na którym zgromadzono wiele starych i nowych ksiąg żydowskich, w których sprawa krwi nie jest ostatecznie załatwiona".

36 L. Haber, "Przyjaciel Ludu”, 1846, nr 20, s. 159, cytuję za: Oskar Kolberg, Lud. Jego zwyczaje, sposób życia, mowa, przystowia, obrzędy, gusła, zabawy, pieśni, muzyka, tańce, t. 48: Tarnowskie-Rzeszowskie, Wrocław-Poznań 1961, s. 17-18.

37 LK 72, 73, 85, 86 etc. O dziewiętnastowiecznych perypetiach motywu zob.: M. Wodziński, Oświecenie żydowskie w Królestwie Polskim wobec chasydyzmu. Dzieje pewnej idei, Warszawa 2003, s. 77, 76, 149-151, 179-181, 262.

38 LK 424.

39 Zawarty w Żywotach Świętych scenariusz mordu rytualnego, oparty na żywocie św. Szymona z Trydentu †1495, odpisanym od Tabarina, lekarza, dokonującego obdukcji zwłok małego Szymona, w języku polskim, pojawił się w pierwszym wydaniu Żywotów (1579), ostatni raz w: Piotr Skarga, Zywoty Swiętych Starego y Nowego Zakonu na każdy dzień przez cały rok, Wyd. Księży Jezuitów, Kraków 1933. 
z Trydentu, zostało wydane - bez komentarzy - przez księży Jezuitów w Krakowie w roku 1933, zamiast pytać o to, czy polscy biskupi mogli wierzyć w żydowskie mordy rytualne w latach 1945-1946, należało by raczej zapytać, jak mogliby w nie nie wierzyć. O trwałości formacji światopoglądowej polskiego Kościoła powojennego można się przekonać, studiując dzieła wydawane po wojnie przez niektórych biskupów ${ }^{40}$, a także przyglądając się otoczeniu kolejnych hierarchów ${ }^{41}$.

\section{Żotnierze i oficerowie podziemia}

Mniej oczywiste od pytania o kler wydaje się pytanie, czy w legendę o krwi mogli wierzyć żołnierze i oficerowie WiN-u i innych organizacji konspiracyjnych, redagujący podziemne biuletyny i ulotki oraz piszący raporty dla rządu londyńskiego.

Jak wynika z kwerendy, w tekstach WiN-u spotyka się szczególnie natężenie antysemity$z^{42}$. Idea spisku żydowskiego przybiera tu rozmiary obsesji. Jak $w$ tekście następującym:

„zasadniczym celem Światowego Rządu Żydowskiego z siedzibą w Palestynie jest stworzenie jednego państwa światowego pod ich [Żydów] hegemonią. Rząd ten reprezentuje kapitalistyczny zachód i komunistyczny wschód, a wszystko po to, by realizować wspólne postulaty polityki żydowskiej. Ich wspólnym cechem jest opanowanie świata. Pewne koła rządu żydowskiego popierają rewolucyjne wysiłki żydostwa komunistycznego, celem zapewnienia Żydom w tych ustrojach objęcie stanowisk uprzywilejowanych"43.

Piśmiennictwu temu, z reguły posługującemu się religijno-narodową figurą Krwiopijcy często towarzyszy szczera wiara w mord rytualny. Wyjąwszy odezwy, większość tekstów, które przytocze stanowią meldunki tzw. Brygad Wywiadowczych WiN ${ }^{44}$. Tekst pierwszy został zidentyfikowany jako "raport wywiadowczy Okręgu Krakowsko-Rzeszowskiego Delegatury Sił Zbrojnych na Kraj"45. Wypływa w nich topos "sekty zagorzałych fanatyków", tym ciekawszy, że wiążący ich z "chasydami"46.

\section{$\cdots \cdots$}

40 Bp Karol Radoński, Święci i błogostawieni Kościoła Katolickiego. Encyklopedia hagiograficzna, WarszawaPoznań-Lublin 1947; tam zob. np. żywot Wernera z Oberwesel, Szymona z Trydentu etc.

$41 \mathrm{~Np}$. jedna z najważniejszych osób w otoczeniu bp. Wyszyńskiego - ksiądz Józef Kruszyński, powojenny rektor KUL. Przed wojną m.in. autor następujących książek: Żydzi i kwestia żydowska, Włocławek 1920; Dążenia żydów w dobie obecnej, Włocławek 1921; Polityka żydowska, Włocławek 1921; Żargon żydowski, Włocławek 1921; O narodowy język żydów, Włocławek 1921; Żydzi a Polska, Poznań 1921; Religia żydów wspótczesnych, Włocławek 1923; Dlaczego występuję przeciwko Żydom?, Włocławek 1923; Rola światowa żydostwa, Włocławek 1923; Dlaczego wystepuje przeciwko żydom?, Kielce 1923; Niebezpieczeństwo żydowskie, Włocławek 1923; Antysemityzm, antyjudaizm, antygoizm, Włocławek 1924; Żydzi a świat chrześcijański, Włoctawek 1924; Stanistaw Staszic a kwestia żydowska, Lublin 1925; Talmud co zawiera i czego naucza, Lublin 1925. Zob.też Dariusz Libionka, Księdza Kruszyńskiego șpojrzenie na Zagładę, „Gazeta Wyborcza“(Lublin), 26/1/2008; tegoż, Obcy, wrodzy, niebezpieczni. Obraz Żydów i "kwestii żydowskiej" w prasie inteligencji katolickiej lat 1930. w Polsce, "Kwartalnik Żydowskiego Instytutu Historycznego", nr 3 (203): 2002.

42 Na temat antysemickich dokumentów o proweniencji WiN-owskiej pisze Julian Kwiek, "Ogień« wobec mniejszości narodowych, w: Wokót legendy "Ognia». Opór przeciw zniewoleniu: Polska-Malopolska-Podhale 1945-1956, Nowy Targ 2008, s. 244. Także tegoż, Żydzi, Łemkowie, Stowacy w województwie krakowskim w latach 1945-1959, Kraków 2002.

43 Archiwum Państwowe w Krakowie, zespół Zrzeszenie "Wolność i Niezawistość", 9, k. 72: Mniejszości narodowe, za: Kwiek, dz. cyt., s. 243-257.

44 Krzysztof Kaczmarski pisze, że nazwa nawiązuje do pionu politycznego (tzw. defensywy) przedwojennej Policji Państwowej. W okresie okupacji wchodzity one w struktury Oddziałów Bezpieczeństwa Wydziatów Wojskowych, działających przy okręgach ZWZ-AK. Do końca 1944 r. rzeszowskie Brygady Wywiadowcze podlegały komendzie Okręgu ZWZ-AK Kraków, potem zostały podporządkowane "NIE«, a od maja 1945 r. Delegaturze Sił Zbrojnych. Od września 1945 r. tworzyły równorzędną i niezależną siatkę wywiadowczą Zrzeszenia „Wolność i Niezawisłość”, K. Kaczmarski, Pogrom, którego nie było - wydarzenia w Rzeszowie 11-12 czerwca 1945, "Glaukopis”, nr 11-12: 2008, s. 295, przyp. 20. Zob. też Z. Nawrocki, Brygady Wywiadowcze (1940-1946) - zarys problematyki, „Zeszyty Historyczne WIN-u”, nr 18: 2002, s. 33-48; tegoż, Zamiast wolności. UB na Rzeszowszczyźnie 1944-1949, Rzeszów 1998, s. 140-146.

Kaczm. 104

46 O kojarzeniu chasydów z blood libel w wieku XIX zob. Wodziński, Oświecenie żydowskie w Królestwie Polskim wobec chasydyzmu, dz. cyt., s. 150. 
W meldunkach i odezwach podziemnych jeszcze silniej niż w omawianych wcześniej listach prywatnych zarysowuje się migracja legendy o krwi w sferę mitu narodowego. Terminologię religijną („dzieci chrześcijańskie“ lub „katolickie“) zupełnie wypiera narodowa („dzieci polskie“)47. Nawet tam, gdzie pojawiają się sygnały leksyki religijnej („rabin“, "chasydzi", "mord rytualny"), oscyluje ona ku asocjacjom narodowym (tekst 1). W poniższych tekstach podkreślam je rozspacjowaniami.

Tekst 1

[raport wywiadowczy Delegatury Sit Zbrojnych na Kraj?]

„Rzeszów. Przed dziesięciu dniami wykryto na terenie Rzeszowa potworną zbrodnię żydowską dokonaną na 16 dzieciach polskich, które zabito rytualnie na krew, do praktyk chasydzkich. Zbrodnia ta wywołała duży odruch społeczeństwa, tak że poważne ilości żydów uciekła do Tarnowa, rozpuszczając usprawiedliwienia, że brali krew na transfuzję (gdy tymczasem w czasie rewizji znaleziono flaszeczke z krwią" ${ }^{\prime 4}$.

Tekst 2

[raport Brygad Wywiadowczych, jesień 1945]

„W piwnicy Żyda rabina przy ul. Tannenbauma [w Rzeszowie] nakryto rabina w pokrwawionym kitlu przy wiszącej na dół głową nieżywej dziewczynie. Zaalarmowany przechodzący patrol milicji ustalit poza tym części ciała ludzkiego, należące do 16 osób. Wzięty w obroty rabin załamał się i przyznat, że są to pozostałości 16 dzieci. Twierdził jednak, że nie są to mordy rytualne, ale na ród żydows ki poniósł wielkie straty i wiele jego najwybitniejszych jednostek musi być dożywiane krwią ludzką, którą to tą drogą się zdobywa. Na wiadomość o powyższym zajściu ludność rzuciła się na Ż y d ó w, przeprowadzając pogrom. W międzyczasie wmieszało się NKWD i UB. Wzięło w obronę Ż y d ó w (...)"49.

Tekst 3

[sprawozdanie WiN, jesień 1945]

„Dnia 11 V [1945 [r.] w piwnicy ży do ws kiej w Rzeszowie przy ulicy Tanenbauma przyłapano rabina w pokrwawionym kitlu przy wiszącej na dół głową nieżywej dziewczynie (Bronistawa Mendoń, c ó r k a p ol s k i e g o r o b o t n i ka, który przez 3 lata ukrywał u siebie Ż y d ó w przed Niemcami ${ }^{50}$ ). Zaalarmowany przechodzący patrol MO ustalit przy tym części ciała ludzkiego, należące do 16 osób. Wzięty w obroty rabin załamał się i przyznał, że są to pozostałości 16 dzieci. Twierdził jednak, że nie są to mordy rytualne, ale na ród ży do w s k i poniósł wielkie straty i wielu jego najwybitniejszych przedstawicieli musi być podtrzymywanych krwią ludzką! Krew zdobywa się właśnie tą drogą! Na wiadomość o powyższym ludność rzuciła się na Ż y d ó w bijąc ich. W międzyczasie wmieszało się NKWD i UB. Wzięto Ży dó w w obronę (...)" ${ }^{\prime 5}$.

\footnotetext{
47 Leksyka religijna przetrwała natomiast w zeznaniach i meldunkach Żydów.

48 Ten dokument stanowi jedyną wzmiankę o mordach rytualnych w interesującym zbiorze meldunków z lat 1945-1946, Różne raporty i sprawozdania za okres maj-lipiec 1945, k. 109, Biblioteka Uniwersytetu Warszawskiego, Czytelnia mikrofilmów, mkfm 8614, k. 109. Krzysztof Kaczmarski, który też cytuje powyższy tekst, sądzi, że jest to „raport wywiadowczy Okręgu Krakowsko-Rzeszowskiego (?) Delegatury Sit Zbrojnych na Kraj", Kaczm. 104.

49 Załącznik do raportu Okręgu Rzeszowskiego Brygad Wywiadowczych, 15?/9/1945, AIPN Rz, 122/312, k. 218, za: Kaczm. 142, dok. 33. W dokumentach WiN-owskich istnieje seria tekstów spokrewnionych leksykalnie i operujących podobnymi danymi (np. liczba 16 ofiar), rozwijających ten właśnie wariant.

50 K. Kaczmarski, Pogrom, którego nie było - wydarzenia w Rzeszowie 11-12 czerwca 1945, "Glaukopis", dz. cyt., s. 294: „Informacji tej w rozmowie z autorem nie potwierdził Franciszek Mendoń, syn Stanisława. Przyznał natomiast, że Żydom pomagał jego wuj, brat Stanisława - Władysław Mendoń mieszkający przy ul. Stowackiego. Zob.: AIPN, 944/64, Akta w sprawie przeciwko Ł. Cieplińskiemu i innym (IV ZG WiN), Sprawozdanie z zajść antyżydowskich w Rzeszowie z dnia 11/06/1945, k. 459; relacja ustna Franciszka Mendonia z 3 IV 2008

51 Załącznik do sprawozdania Zrzeszenia WiN na temat zajść antyżydowskich w Rzeszowie, jesień 1945, za: Kaczm., dok. 34, s. 143. Meldunek pokrewny leksykalnie: opracowanie Zrzeszenia WiN na temat polityki narodowościowej PPR, za: Kaczm., dok. 43, s. 162, druga poł. 1946 r.
} 
Tekst 4

[Lublin, ulotka sygnowana Polska Antykomunistyczna Organizacja Wojskowa, kwiecień 1945]

„Ż y d z i, przeszliście okres prześladowań hitlerowskich. Każdy z was ocalał, zdobył swe życie jedynie dzięki P ol a ko m. Teraz po wkroczeniu Armii Czerwonej wyszliście ze swoich kryjówek tylko dlatego, żeby gnębić praw dzi w y c h Pola kó w, a swoich wybawicieli. Wydajecie na zagładę tych, którzy w najbardziej krytycznych godzinach wyciągnęli do was rękę. Ż y d z i! Okazaliście się wrogami P o l a k ó w"52.

Tekst 5

[Brygady Wywiadowcze, 26/06/1945?]

„Nastroje antysemickie spowodowane współpracą Ż y dó w z e S o w i e ta m i i rządem lubelskim pod pływem mordu rytualnego przybrały rozmiary rozruchów" 53 .

Tekst 6

[Kraków, anonimowa odezwa, po pogromie sierpniowym 1945]

„PPS. Wojsko i pachołki żydów!

Żydzi mordercy - precz z wami!

PPS. organizuje pijawki krwi polski ej!

PPS. tworzy korpus ochrony żydów!

Pomścimy morderców d z i e c i pols k i c h!

PPS. pachołki żydów! ${ }^{54}$

Tekst 7

[Kraków, ulotka anonimowa, po pogromie sierpniowym 1945]

„Oto Żydzi, nasz odwieczny wróg, przy ulicy Miodowej w synagodze popełnili mord na p o Iskich dziecia ch. Ilu zginęło dzieci? Nie wiadomo. Po Rzeszowie, Tarnowie, miejscem żydowskich morderców stał się Kraków. Fakty same mówią za siebie. (...) Po faktach Tarnowa i Rzeszowa mord jest zrozumiałym i jest synonimem stosunku n a rod u Ż y d o w s ki e go do tego wszystkiego, co jest dla nas drogie. A więc P ola c y - Niemiec nasz wróg, Bolszewik tak samo, a trzecim to Ż y d. I teraz są nam jasne wypadki uliczne, gdzie Bolszewicy chowali pod «skrzydła swe opiekuńcze« Żydów, bijąc po twarzach Polaków i strzelając do Narodu, który stawał w obronie Polaka oficera. Nie ma miejsca w Polsce dla Niemca, Bolszewika i Żyda. POLSKA DLA POLAKÓW"55.

Tekst 8

[Kraków 1945, ulotka z 12/08/1945, sygnowana przez „"Odwet« O.Z.N”; fragment]

„Bij Żydów! Za pomordowane d z i e c i pols k i e przy ul. Starowiślnej w bóżnicy“56.

Tekst 9

[Lublin, ulotka sygnowana „Cierń", 1945?]

„Ż y d z i! Czas waszego dobrobytu skończył się, częściowo z czasem masowego mordowania was przez Niemców, a resztę niedobitków ocalałych z pogromu wykończymy my. W P o I s ce dla was miejsca nie ma, broń wasza wam nie pomoże. I poczekajcie jeszcze trochę,

52 Cyt. za: I. Gutman, S. Krakowski, Unequal Victims. Poles and Jews During World War Two, New York 1986, za: A. Kopciowski, Zajścia antyżydowskie na Lubelszczyźnie w pierwszych latach po drugiej wojnie światowej [dalej: Kopciowski], w: Zagłada Żydów. Studia i materiały, t. 3, Warszawa 2007, s. 183, przyp. 20.

53 Raport Okręgowego Rzeszowskiego Brygad Wywiadowczych, 6/06/1946, za: Kaczm., dok. 19, s. 109

54 Anonimowa ulotka rozpowszechniana w Krakowie po wydarzeniach antyżydowskich 11 sierpnia, CAW, sygn. 767/322, k. 96, za: A. Cichopek, Pogrom Żydów w Krakowie 11 sierpnia 1945 r., Warszawa 2000 (dalej: Cichopek), 227, dok. nr 59.

55 Anonimowa ulotka rozpowszechniana w Krakowie po wydarzeniach sierpnia 1945 r., Cichopek 197-198, dok. $\mathrm{nr} 49$.

56 Cichopek 93, przyp. 107, bez identyfikacji grupy podziemnej. 
a przekonacie się, że nie są to czcze słowa. Byli Niemcy, Polaków wydawaliście, są inni - robicie to samo. Dość waszych rządów. Miejsce wasze jest albo w ziemi, albo w Palestynie"57.

Tekst 10

[Krakowskie, anonimowa ulotka, 1945]

„Do Łodzi przybyło 60.000 ż y d ó w z Rosji - tych, którzy w roku 1920 i 21 na wschodzie lali wrzącą wodę i strzelali do w o j s k a pols k i e go. Daje im się piękne fabryki, przemysłowe obiekty, tworzy się milicję i służbę bezpieczeństwa - polskie NKWD. W lochach giną najlepsi synowie ojczyzny, a szefowie tych agend są dobrze płatni przez Sowietów i międzynarodowe żydostwo (...). Ostatnio otrzymaliśmy wiadomość, że każda żydówka rodząca syna otrzymuje 25 tysięcy, zaś za córkę 20 tysięcy z Kachału [tak w oryg.], a Kachał otrzymuje subwencję od Rządu, a my płacimy podatki" 58 .

Tekst 11

[odezwa sygnowana "Ogień", adresowana do pracowników „Bezpieki"; fragmenty, ortografia oryginału]

„ŚMIERĆ SŁUŻBIE BEZPIECZEŃSTWA I OCHYDNYM Ż Y D O M!!!!!!!! Udeżcie się we własne sumienie, ile wyżądziliście krzywdy, cierpienia i bulu swoim braciom. Dziś jęczom po więzieniach [do] których wy [ich] doprowadziliście i oddali w ręce katowskie. Wspomnijcie matki, żony i sieroty, które wylewają gożkie tzy i wołają o pomstę do nieba, aby jak najprędzej zginęli mordercy, którzy w barbarzyński sposób znęcają się nad swemi braćmi. Lecz którz jest większym mordercą? Czy ten, który katuje, czy ten, który zdradza i aresztuje. O synu nie wierny! O psie podły! Dlaczego za marny grosz strzelasz do swojego brata, który walczy o lepszą dolę? Dlaczego znęcasz się nad nim jak dziki zwierz? Za co ty służysz i dla kogo pracujesz? Dla komuny i ż y d a!!!!!!! Wstyć się żołnierzu służby chorowej [? poborowej?] która zwię się bezpieka. Urządzając tapanki w wioskach $\mathrm{p} \mathrm{r}$ a w d z i w y c $\mathrm{h}$ P o la kó w, w pierwszym rzędzie zabierasz ostatnią kromkę chleba d z i e c i o m po I s k i m i rabujesz, co tylko wpadnie w ręce. (...) B r a cia Pola cy! Nadszedł czas kiedy będziemy bezwzględni i nieubłagani. Zginie każdy żyd (pijawka krwi polskiej) PPR (płatni pachołkowie Rosyjscy). (...) Po raz ostatni wzywamy ludność Nowego Targu do poprawy i wytrwania w d u ch u pols ki m. Skończcie ze zdradą, własnym zyskiem, dopomóżcie nam a my was wyzwolimy i oswobodzimy" 59 .

Przytoczone teksty przynoszą dychotomiczny obraz dwóch wrogich sobie, skrajnie zetnizowanych idei, wpisanych w opozycje:

\author{
Krwiopijca / ofiara \\ "żydokomuna" / "Naród Polski” \\ Antagonista / Bohater \\ Pomocnik Antagonisty/Pomocnik Bohatera \\ agresja / martyrologia \\ obcość / swojskość \\ zwierzęcość/ludzkość \\ zbrodniczość/ niewinność, \\ niewdzięczność/wdzięczność \\ kradzież/krzywda
}

\title{
- ...
}

57 Archiwum Państwowe w Lublinie, Ulotki wydawane po wyzwoleniu, sygn. 120, k. 20, za: Kopciowski 182, przyp. 17.

58 Anonimowa ulotka rozpowszechniana w województwie krakowskim, kończąca się hasłem: „Niech żyje Polski Rząd w Londynie!", 1945 Kraków, za: Cichopek 232-233, dok. nr 61.

59 Cyt. za facsimile w: Kwiek, "Ogień « wobec mniejszości narodowych, dz. cyt., s. 257. 


\section{Krwiopijca/ofiara: udostownienie metafor}

Autorzy meldunków WiN-owskich (1-3), a także ulotek (5-8) wierzyli w to, że Żydzi wzmacniają się krwią "polskich dzieci“.

W tekście 2 doprecyzowano zmodernizowany wariant mitu o krwi: nie jest on, słyszymy, mordem rytualnym, tylko wymuszaniem krwi dla dożywiania Żydów. Objaśniający sytuację rabin stanowi porte parole żołnierzy WiN-u, którzy legendę o krwi pragnęli unowocześnić, urealnić. Najbardziej neutralne, wyprane ze skojarzeń religijnych sformułowanie wątku przynosi tekst cytowany w przypisie ${ }^{60}$, gdzie mowa jest o dziewczynce „zmarłej na skutek wycieku krwi pobranej dla celów transfuzji", a żydowskich sprawców określa się mianem „konfidentów NKWD“. Odium zbrodni "transfuzyjnej” przechodzi tu na instytucje policyjne: UB, NKWD (teksty 2, 3, 10, 11), a także PPR (11), „Sowietów“ (5) i "bolszewików" (7). To oni są teraz współkrwiopijcami, zbiorowym Pomocnikiem Antagonisty. W opinii autora ulotki nr 6 dołączają do nich „PPS" i „wojsko".

Zaskakujące, że w funkcji Pomocnika Bohatera kilkakrotnie występuje "zaalarmowana milicja" (teksty 2, 3). W logice legendy o krwi akt ten wpisuje się w funkcję zwycięstwo/zdemaskowanie Antagonisty (Ex), którą zwykle obsadzali pastuszkowie lub pobożni chrześcijanie. W jednym z meldunków podziemnych (tekst cytowany w przypisie ${ }^{61}$ ) mowa jest o tym, że odkrycie zbrodni patrol przypłaca własnym zniknięciem. Mit przewiduje na to miejsce w schemacie - np. w legendzie o hostii poznańskiej (1399) odpowiada mu uwięzienie w miejskiej ciemnicy pasterza, który odkrył żydowską zbrodnię ${ }^{62}$. Z tego, że w podziemnych meldunkach o milicjantach mówi się z sympatią wynika, że w odróżnieniu od UB i NKWD, to jest instytucji „broniących Żydów“, władza, której uosobieniem byli milicjanci, przez konspirujących oficerów nie była odczuwana jako całkowicie zła czy obca. Wyrażaną w listach prywatnych ludową opozycję "wojsko polskie"/ "wojsko sowieckie" w tekstach ulotek i meldunków zastępuje opozycja "milicjanci“/UB-NKWD.

Teksty $(1,2,3,5,6,7,8)$ reprezentują rozmaity poziom intelektualny, ale w mniej lub bardziej zmodernizowanej wersji wszystkie transmitują legendę o krwi. Emocją, jaka je łączy jest przeświadczenie o zagrożeniu biologicznej egzystencji narodu polskiego. Wyraża się ono figurą porwanego i zamordowanego dziecka, w legendzie o krwi będącego sy-

Broszura Dość kretactw sowieckich: „11.06.br. w Rzeszowie, gdzie przy ul. Tanenbauma 12 znaleziono zwłoki 9-letniej Bronisławy Mendoń zmarłej na skutek wycieku krwi pobranej dla celów transfuzji”. W dalszym ciągu tekstu mówi się, że sprawców mordu rzeszowskiego ujęto. Mieli być nimi czterej konfidenci NKWD - Żydzi, którzy po kilku dniach na żądanie NKWD wypuszczono. „A więc mord, jeżeli nie był dokonany na żądanie NKWD, to w każdym razie był przez NKWD aprobowany". AAN, KC PPR, 295/VII-203, k. 57, za: J. Kwiek, Wydarzenia antyżydowskie 11 sierpnia 1945 w Krakowie, „Kwartalnik Historii Żydów”, nr 1 (193): 2000, s. 83-85. Dziękuję Panu Prof. Julianowi Kwiekowi za udostępnienie mi swoich tekstów i pómoc bibliograficzną.

61 Zob. meldunek Brygad Wywiadowczych: „Cały patrol MO, który przeprowadził pierwsze dochodzenie zosta aresztowany i ślad po nim zaginął. Zostali również aresztowani ludzie, którzy byli świadkami zajścia w piwnicy. Sam rabin przebywał w więzieniu rzeszowskiego UB, gdzie szczerze przyznawał się do dokonanego mordu, tak do współwięźniów polskich politycznych, jak i funkcjonariuszy UB. W parę dni potem na rozkaz Ministerstwa Bezpieczeństwa został przesłany z więzienia rzeszowskiego, a sprawa dochodzeń została umorzona", Sprawozdanie z zajść antyżydowskich w Rzeszowie z dnia 11/06/1945, AIPN, k. 459, 944/64, za: Kaczmarski, Pogrom, którego nie było, "Glaukopis”, nr 11-12: 2008, s. 302, przyp. 80. Powyższa oplotke o zniknięciu patrolu podjęli niektórzy historycy, ostatecznie jednak na podstawie odnalezionych materiałów śledztwa została ona sfalsyfikowana. Zob. Kaczmarski, tamże: „W aktach osobowych milicjantów, o których wiadomo, że kierowali, względnie uczestniczyli w rewizji i zatrzymaniu Żydów (Jan Grzeszek, Maria Bzura, Franciszek Kaszuba, Jan Łukasz, Marcin Opiekun, Jan Siatko, Władysław Niedzielski, Zygmunt Stachura) nie ma jakichkolwiek informacji o ich aresztowaniu lub zwolnieniu ze służby w związku z tą sprawą. Brak również potwierdzenia informacji o aresztowaniu rabina Thorna przez UB".

62 Narracja 59M pióra x. Tretera, w: LK, s. 312. Wątek ten będzie się pojawiać we wszystkich spiskowych teoriach pogromów. Np. w Krakowie miał zniknąć Antoni Nijaki, trzynastolatek, który krzyczat, że Żydzi chcieli go zamordować, zob. dokument WiN-owski Sprawozdanie z zajść antysemickich w Krakowie, APKr, zespó WiN, t. 31, k. 43-432, cyt. za: Kwiek, Wydarzenia antyżydowskie 11 sierpnia 1945 w Krakowie, dz. cyt., s. 83. Julian Kwiek podaje, że Antoni Nijaki został zwolniony z aresztu 22 października 1945 r., tamże, przyp. 15. 
nekdochą Ciała Narodowego. Zabicie dziecka stanowi zamach na żywotne interesy grupy. Dostowne wykrwawianie ofiar stanowi krok na drodze udosłownienia Krwiopijcy, co staje się spustem przemocy63. Dopóki obcujemy z „pijawką“ (teksty 6, 11)64 czy nawet „żydowskimi pluskwami“"65, przemoc ma charakter symboliczny. Sytuacja zmienia się, odkąd w konkretnej „ż̇ydowskiej piwnicy“ (3), „piwnicy Żyda rabina“ (2) pojawia się realny Żyd „W pokrwawionym kitlu przy wiszącej na dół głową nieżywej dziewczynie“ (2) ${ }^{66}$. Znamy nawet jego nazwisko: rabin nazywa się Leib Thorn ${ }^{67}$.

W polskich odmianach blood libel za narzędzie wykrwawiania ofiar uważano beczkę z kolcami (jak na malowidle Karola de Prêvot w katedrze sandomierskiej). Czasem obraz beczki w legendzie bywał wypierany przez figurę „uboju rytualnego", którą jako praktykę żydowskich rzezaków dobrze pamiętali polscy sąsiedzi. W okresie międzywojennym praktyka ta fascynowała rodzimych żydoznawców ${ }^{68}$. Można podejrzewać, że to właśnie za jej pośrednictwem dokonywała się modernizacja legendy o krwi i jej przesunięcie z dyskursu religijnego w narodowy ${ }^{69}$. Potwierdzenie domysłu znajdujemy we frazeologii prasy konfesyjnej okresu międzywojennego, w której napotykamy określenia typu „ubój narodu polskiego"70.Ten „ubój” opisują trzy drastyczne meldunki żołnierzy podziemia. Obraz Broni Mendoń, nad którą pastwi się "rabin w pokrwawionym kitlu“, to jednocześnie symbol „uboju narodu polskiego“ dokonanego przez inwazję „żydokomunistów“. Znaczenia dosłowne i metaforyczne oscylują i stale zamieniają się miejscami.

Czym obraz uboju różni się od obrazu wykrwawiania dzieci w beczce? Różni się dehumanizacją ofiary - „nieżywej dziewczyny" - Polski¹, którą przedstawia się jako zwierzę rzeźne. Niewielka zmiana w symbolice nasila pragnienie zupełnie realnego odwetu ${ }^{72}$.

\section{$\cdots \cdots$}

63 Zob. H. Segal, Marzenie senne, wyobraźnia i sztuka, przeł. P. Dybel, Kraków 2003. Operacja udostownienia, w kategoriach Hanny Segal zrównania symbolicznego, polega na patologicznym „zrównaniu (utożsamieniu) symbolu z obiektem, który reprezentuje. W wyniku tego procesu realny obiekt o (nieuświadamianym) znaczeniu symbolicznym przestaje być rozpoznawany przez jednostkę jako to, czym faktycznie jest (...), ale przeobraża się dosłownie w to, co sobą symbolizuje”. Wywiad z Hanną Segal, "Gazeta Wyborcza”/,Wysokie Obcasy", 7/02/2004. Zob. też: LK 183.

64 Zob. A. Cała, Wizerunek Żyda w polskiej kulturze ludowej, dz. cyt., s. 52: „pijawki krwi naszej”.

65 Kwiek, Żydzi, Łemkowie i Stowacy, dz. cyt., s. 74.

66 Określenie musiało stanowić silny topos folklorystyczny, skoro jeszcze w roku 2005 zostało odnotowane $w$ trakcie badań etnograficznych na Sandomierszczyźnie. Pojawiało się w tzw. memoracie, to jest w opowieści świadka (lub bliskiej mu osoby), który podczas odwiedzin w żydowskim domu widział wiszącego głową w dół "Polaka w szafie”.

67 Biogram rabina Leiba Thorna, który zamieszkiwał przy ul. Tanenbauma 12, a przez pewien czas był także kapelanem wojskowym w Warszawie, zob. Kaczm. 78. O dalszych losach Thorna, który kilka dni po pogromie odwiedził podobno Rzeszów, zob. J.T. Gross, Strach. Antysemityzm w Polsce tuż po wojnie. Historia moralnej zapaści, Kraków 2007, s. 79-82.

68 Miarą tej fascynacji może być to, że w przededniu wojny zagadnieniem żydowskiego uboju rytualnego zajmowały się powstające spontanicznie komitety obywatelskie (zob. np. Protokót zebrania organizacyjnego przedstawicieli ludności chrześcijańskiej miasta uzdrowiska Otwocka, odbytego 25 // 1936 roku w Otwocku w sprawie walki z rytualnym ubojem na terenie miasta i uzdrowiska Otwocka, http://dziedzictwo.polska.pl/ katalog/index,Zydzi,cid,1477.htm?sh=61, dostęp: 22/3/2010). Zob. też ks. Stanisław Trzeciak, Ubój rytualny czy mechaniczny - Opinia rzeczoznawcy wypowiedziana na posiedzeniu komisji Administracyjno-Gospodarczej Sejmu Polskiego w dn. 5 marca 1936, pod przewodnictwem Pana Posta Kazimierza Ducha, Warszawa 1936

69 Por. np. wypowiedź zanotowana pod Sandomierzem w roku 2005 (nr transkrypcji 1349) o obrazie Karola de Prêvot z katedry sandomierskiej: „właśnie ten obrzęd, związany z zabijaniem zwierząt koszernych, został tutaj przedstawiony na okoliczność zabijania dziecka". LK, s. XX.

70 Libionka, Obcy wrodzy, niebezpieczni, dz. cyt.

71 O obrazie Polski jako kobiety, młodej dziewczyny zob. np. T. Todorov, Skazani na heroizm, przet. P. Sawicka, "Gazeta Wyborcza" 18/04/1998.

72 "Zapowiada ją tekst w gazecie podziemnej „Honor i Ojczyzna” z lata roku 1946: „Opinia kraju została znów wstrzaśnięta potworna zbrodnia, jaka ludzie w mundurach popełnili na Polakach. Podkreślamy: Żydzi na Polakach, zdecydowanie rasowe zabarwienie miał bowiem bestialski mord, ofiarą którego padli bezbronni członkowie b. AK, a wśród nich jeden z najzdolniejszych malarzy młodego pokolenia Kazimierz Markwart, któremu nawisem mówiąc ojca zamęczyło gestapo. Tło sprawy wygląda w ten sposób, że Żydzi otrzymali od władz bezpieczeństwa zezwolenie na «egzekucję" stukilkudziesięciu Polaków jako zadośćuczynienie za Kielce. Zbrodni dokonano w celach. Wieszano ludzi na rzeźnickich hakach. (...) Kategorycznie żądamy: by na 


\begin{tabular}{|c|c|c|}
\hline \multicolumn{3}{|c|}{ Znaczenie } \\
\hline dostowne & metaforyczne & dostowne \\
\hline $\begin{array}{l}\text { Żyd jako rzezak, } \\
\text { wykrwawiający } \\
\text { zwierzęta }\end{array}$ & „ubój Narodu Polskiego" & $\begin{array}{l}\text { Żyd jako morderca } \\
\text { „dzieci polskich“, } \\
\text { np. Broni Mendoń z Rzeszowa } \\
\text { (zob. przyp. 74) }\end{array}$ \\
\hline $\begin{array}{l}\text { Żyd jako Krwiopijca } \rightarrow \\
\text { z religijnej legendy o krwi }\end{array}$ & $\begin{array}{l}\text { Żyd, ukrywany przez Polaków } \leftarrow \\
\text { jako dręczyciel polskich dzieci, } \\
\text { którym przez } 5 \text { lat odejmował } \\
\text { chleb od ust (patrz dalej) }\end{array}$ & $\begin{array}{l}\text { Żyd jako morderca } \\
\text { polskich oficerów } \\
\text { (Katyń) }{ }^{73}\end{array}$ \\
\hline
\end{tabular}

Ryc. 4. Krwiopijca, migracja znaczenia w figurze „uboju Narodu Polskiego”, rok 1945/1946.

\section{"Żydokomuna"/,"Naród Polski"}

Stan świadomości autorów meldunków i ulotek świadczy o sukcesie przedsięwzięcia, zapowiadanego w rozkazie Mieczysława Liniarskiego - "Mścisława“, jednego z przywódców podziemia poakowskiego. W rozkazie czytamy:

„My reprezentujemy cały Naród Polski - chcemy stworzyć podział: Polacy-Sowiety [...], prze-

konać to społeczeństwo, że cały naród jest z nami, a po drugiej są tylko Sowiety i Żydzi"74.

Identyfikacja Żydów z komunizmem, powszechna w ulotkach, wyraża się w figurze "żydokomuny“75. Ponieważ dyskusja nad tym pojęciem zazwyczaj grzęźnie w sporze o sformułowanie "nadreprezentacja Żydów w UB“, po metodologiczny komentarz w tej sprawie odsyłam do przypisu7. W niniejszym tekście kategorię „żydokomuna" traktuję jako cliché, to jest figurę retoryczną, która:

\section{- •. •}

temat Radomia, a także innych wystąpień Żydów w Polsce zabrały głos czynniki odpowiedzialne za mordalne oblicze społeczeństwa [żydowskiego? - K. K.] w społeczeństwie. Niech zajmie stanowisko żydowskie duchowieństwo, niech wypowiedzą się uczeni, artyści i pisarze, podobnie jak uczynili to Polacy w sprawie Kielc. Niech przemówią i niech odetną się od zbirów w mundurach UBP. W przeciwnym wypadku będziemy zmuszeni odpowiedzialnością za popełnione zbrodnie obciążyć wszystkich Zydów w Polsce jako jedną wrogą nam całość. Antysemitami nie jesteśmy, interes własnego narodu stawiamy jednak ponad wszystko", „Honor i Ojczyzna", nr 9-10: 1946, cyt. za: K. Kersten, Polacy, Żydzi, komunizm. Anatomia pótprawd 193968, Niezależna Oficyna Wydawnicza, Warszawa 1992 (dalej: Kersten I), s. 131.

73 Zob. meldunek milicjanta Michała Kołacza, Rzeszów 12/06/1945, drugi dzień pogromu rzeszowskiego: „Okoto godziny pierwszej po południu przechodząc przez Rynek słyszałem rozmowę na temat wykrytego morderstwa następującej treści: "Ot, widzicie, powiada kobieta (...) za to, żeśmy im jeść dawali, za to żeśmy ukrywali ich, to teraz mordują nasze dzieci. I trzeba Katynia, powiada druga, tu mamy Katyń dla naszych biednych dzieci, przez pięć lat męczonych. Oj, żeby tak moje dziecko zginęło, to bym tym żydziakom oczy wydrapała, ani by im w tym Milicja nie pomogła ", za: Kaczm. 70.

74 15/04/1945, za: K. Krajewski, T. Łabuszewski, Białostocki Okręg AK-AKO, VII 1944-VIII 1945, Warszawa 1997, s. 145. Zob. też Steinhaus, Wspomnienia i zapiski, dz. cyt., s. 312: „9/06/1945. (...) dowiedziałem się, że AK ma rozkaz traktować PPR jak Volksdeutschów".

75 Zob. A. Grabski, Żydowski ruch kombatancki w Polsce w latach 1944-1949, Warszawa 2002, s. 35 n. Zob. tegoż, Działalność komunistów wśród Żydów w Polsce (1944-1949), Warszawa 2004, 30 n. J.B. Michlic, Żydokomuna - Anti-Jewish Images and Political Tropes in Modern Poland, „Jahrbuch des Simon Dubnow-Instituts" t. 4: 2005, s. 303-329; tejże, Poland Threatening Other. The Image of the Jew from 1888 to the Present, Lincoln and London 2006.

76 Redukowanie przyczyn wstępowania Żydów po wojnie do UB do kategorii statystycznych („,nadreprezentacja Żydów w UB“) można, za Pierre'em Bourdieu określić „zapoznawaniem przyczyn, warunkującym akceptację skutków”, tj. umacniającym władzę stereotypu. Z dyskryminacji nie można wyjść inaczej niż przez czasową „nadreprezentację". Usiłując skorzystać z emancypacji, "nadreprezentowani” szli do tzw. resortów siłowych, gdzie starali się uzyskać wpływ na własne bezpieczeństwo, po wojnie dramatycznie zagrożone. O sytuacji Żydów w realiach czystki etnicznej na przykładzie Sandomierszczyzny zob. J. Tokarska -Bakir, Następstwa Holokaustu w relacjach żydowskich i w pamięci polskiej prowincji na przykładzie Klimontowa sandomierskiego, [w:] F. Tych, M. Adamczyk-Garbowska [red.], Nastepstwa Zagłady, Warszawa 2010 (w druku). 
„funkcjonuje przez maskowanie jakiegoś stanu rzeczy, to zaś jest równoznaczne z fałszerstwem o tyle, o ile maskuje się jakiś stan rzeczy, spodziewając się że ujawnienie go nie doprowadziłoby do wyboru zgodnego z zamysłami osoby posługującej się cliché" 77 .

Figura „żydokomuny“ polega na takim spleceniu Żydów i komunizmu, by ich współwystąpienie wyglądało na nieprzypadkowe, odsyłało do ukrytego porządku rzeczywistości, do "prawdziwej natury“ i Żydów, i komunizmu, który to zabieg stanowi mityzację w Barthesowskim sensie tego terminu ${ }^{78}$. Służy on wielu aktorom:

- antykomunistom lub/i antysemitom pozwala zabijać Żydów jako komunistów,

- narodowym komunistom lub narodowcom-aspirantom do karier komunistycznych pozwala wyrazić swój gniew na komunistów-Żydów, którzy zajmują Polakom stanowiska we władzach,

- kierując uwagę na aspiracje Żydów do komunistycznych posad, odwraca ją od aspiracji Polaków do tychże posad.

Sylogizm, na którym opiera się figura żydokomuny -

\section{skoro wśród Żydów są komuniści, więc komuniści to Żydzi}

- sprawiał, że etniczny Polak-komunista, podobnie zresztą jak Żyd-niekomunista, stawali się niewyobrażalni. Wspólnota, której głos przynoszą ulotki i meldunki uznawała ich za szum, pozakategorialny brud ${ }^{79}$, błąd w systemie, nie-fakt, coś, czego nie ma. Od uznania określenia „żydokomuna“ za zasadne nie jest daleko do uprawomocnienia sloganu odwrotnego, że „komuniści to Żydzi“, który z kolei już tylko krok dzieli od sylogizmu:

$$
\text { jeśli Polak jest komunistą, przestaje być Polakiem }{ }^{80} \text {. }
$$

To właśnie sugerowano w rozkazie Liniarskiego - „Mścisława”. Rozumowanie powyższe było skutecznym narzędziem kontroli społecznej. Poważnie liczyły się z nim władze komunistyczne ${ }^{81}$. Ewolucja postawy tych władz w stosunku do Żydów, od równouprawnienia mniejszości do coraz bardziej otwartego antysemityzmu, podyktowana była chęcią odzyskania odmówionej im legitymacji narodowej.

Wróćmy do ulotek. Aby wyjaśnić status anomalii "[etniczny] Polak-komunista", przywołuje się w nich wzmiankowaną wcześniej kategorię „pachołków żydowskich“82. Na-

\section{$\bullet \cdot \bullet \cdot$}

77 R. Robin, Badanie pól semantycznych: doświadczenia Ośrodka Leksykologii Politycznej w Saint-Cloud, w: Język i społeczeństwo, wybrał, wstępem opatrzył M. Głowiński, przeł. J. Arnold et al., Warszawa 1980, s. 295.

78 Roland Barthes definiuje mityzację jako proces przestawienia szeregów natury i kultury; to co historyczne, przedstawia się jako wieczne, to co skonstruowane jako naturalne, to co przypadkowe jako konieczne. Zob. Z. Benedyktowicz, C. Robotycki, L. Stomma, R. Tomicki, J.S. Wasilewski, Antropologia kultury w Polsce dziedzictwo, pojęcia inspiracje, "Polska Sztuka Ludowa”, nr 1: 1989, s. 47-48.

79 "Dirt” w sensie Mary Douglas, Purity and Danger (1967, wyd. pol. Czystość i zmaza, 2008).

80 "Przesłankę przemilczaną stanowi tu założenie o sympatiach ideologicznych: komunistycznych, wrodzonych Żydom, i, resp., antykomunistycznych - Polakom.

81 M. Kula, Lewicowy intelektualista wobec pogromu kieleckiego, w: tegoż, Uparta sprawa, dz. cyt., s. 154: „Establishment bardzo chciał się wyzbyć przyklejanej mu etykietki «żydokomuny «. Sam żył w przeświadczeniu o głębokim, otaczającym go antysemityzmie. Skoro chciał i miał krajem rządzić, wolał wyciszać to pole konfliktu. Niektórzy przywódcy komunistyczni czuli się zreszta niezręcznie z uwagi na własne żydowskie pochodzenie. Pragnęli zapomnieć o korzeniach i pragnęli, by sprawa żydowska w Polsce zniknęła - bądź przez emigrację resztek Żydów, bądź przez przemilczanie“. „1/05/1946 (...) Morderstwa Żydów nie ustają. W Niedzielę Wielkanocną zabito w Nowym Targu pięciu wracających z obozów. Ani demokraci, ani PPR nie umieją znaleźć właściwego tonu w tej sprawie. Bo PPR powołuje się na równouprawnienie mas, religii, itp w Polsce, a równocześnie wszystkich Żydów czynnych u siebie i w «bezpiece « maskuje pod nazwiskami polskimi, bojąc się niepopularności wśród swoich własnych dołów", Steinhaus, Wspomnienia i zapiski, dz. cyt., s. 346. Zob. także: Kwiek, Żydzi, Łemkowie, Słowacy, dz. cyt., s. 4.

82 Epitet, którym opatrywano pierwszego prezydenta RP, Gabriela Narutowicza. Marszałek Sejmu Maciej Rataj zapisał w pamiętnikach scenę z 9 XII 1922 r.: „Chodziłem po ulicach i przypatrywałem się bandom włóczącym się, demonstrującym bez przeszkód i polującym na Żydów. Scena na Wiejskiej - jakiś pan w bogatym futrze tłumaczy stróżowi głośno: "wybrali prezydentem złodzieja, żydowskiego pachołka Narutowicza»", za: 
wiązuje ona do określenia "goj w służbie Żyda"83, którego, jak może pamiętamy, autor „Kwartalnika Rodzinnego" z roku 1926 uznał za skandal większy niż samego „żydowskiego Krwiopijcę". W oczach Polaków pachołek ten uchodził za zdrajcę, tak samo jak „przechrzta“" w oczach Żydów. W porządku kategorialnym, w oparciu o który układano stosunki pomiędzy chrześcijanami i Żydami, potem zaś "narodowcami“ i "syjonistami", obaj stanowili nieczystość, anomalię. Określenie „pachołek żydowski” wzbogaciło po wojnie zasób epitetów o historycznej genealogii (każdy z nich ma osobną historię), takich jak „szabesgoj”, „żydowska ciotka“/,żydowski wujek“84/,żydowski kum“85, „opiekunka Żydów"86, "kochanka żydowska“87, „żydowski Wojtek“/ „żydowska patelnia“88. Byli to ludzie łamiący zakaz kontaktowania się z Żydami, który z różnych powodów wspierany był przez obie społeczności (zob. odezwa 7) ${ }^{89}$.

\section{Obcość/swojskość; zwierzęcość/ludzkość}

Obcość Żydów (podwójna: etniczna i ideologiczna) w ulotkach ulega wzmocnieniu przez wskazanie, że przysłano ich z Rosji (tekst 10), wraz z Sowietami. Żydowski zalew i wyzysk („, piękne fabryki, przemysłowe obiekty“) ma się odbywać za aprobatą państwa, Sowietów, „Kachału“ i "międzynarodowego żydostwa“.

Ulotka nr 10 jest zbudowana na rozumowaniu:

Żydzi to robactwo; robactwo się mnoży; Żydzi mnożą się jak robactwo ${ }^{90}$,

na którym opierała się przedwojenna panika etniczna w Niemczech ${ }^{91}$. Jej ślady odkrywamy także w powojennej Polsce. W lipcu roku 1946 donoszono o niej z Jędrzejowa:

"Dziś obiega miasto pogłoska, że w najbliższym czasie do Jędrzejowa napływa kilka tysięcy

Żydów z ZSRR ${ }^{92}$. Rozgoryczenie, rwetes, podniecenie, nerwowość, stan zapalny"93.

Podobne plotki krążyły po Kaliszu i innych miastach ${ }^{94}$. Wspomagały ją pogłoski o wspieranej przez państwo szalonej rozrodczości Żydów. Suma 20 tys. złotych, o której mowa

\section{......}

http://www.przk.pl/nr/historia/tragiczny_los_przypadkow_cz.html (dostęp: 15/4/2010). Epitet alternatywny po wojnie: „moskiewscy pachołkowie”, zob. np. R. Ciernik, Ciosanie, Warszawa 1965, s. 16.

83 Zob. paragraf Trzy wcielenia Krwiopijcy.

84 Tym mianem określano Polaków przechowujących Żydów np. w Rzeszowie, zob. opis sytuacji w czasie pogromu rzeszowskiego z czerwca 1945: „Były wypadki, że Żydzi wpadali do znajomych chrześcijan, by się ukryć, ale cywilna ludność przeszkadzała temu i obrzucała stekiem wzwisk, jak "wujek żydowski«" Sprawozdanie z przebiegu zajść antyżydowskich w Rzeszowie 12/6/1945, sporządzone przez zarząd Żydowskiej Gminy Wyznaniowej w Rzeszowie dla CKŻP, za: Kaczm. 94.

85 Zob. T. Markiel, Zagłada domu Trinczerów, dz. cyt., zob. także zeznanie Zygmunta Talgora z Husowa, 19/06/1950, AIPN Rz 06/23: „Szpecht prosił mnie o kawałek chleba i na te stowa Lew Wojciech zam. w Husowie wyraził się słowami na mnie: "skurwysynu kum żydowski«".

86 Protokót rozprawy gtównej przed Wojskowym Sądem Rejonowym w Kielcach, za: Meducki I 273.

87 Protokót rozprawy gtównej przed Wojskowym Sądem Rejonowym w Kielcach, za: Meducki I 279.

88 Tak nazywano chrześcijan, którzy w oznaczonej porze, tj. w szabas czy święta, za zapłatą podpalali pod kuchnią w żydowskim domu. Zob. F. Kotula, Tamten Rzeszów, czyli wędrówka po zakątkach i historii miasta, Rzeszów 1965, s. 383. „Żydowski Wojtek” to temat gadek i bajek ludowych i przysłów, np. „Każdy Żyd ma swojego Wojtka, a Polak swojego Joska".

89 LK 389, zob. też odezwa nr 7.

90 Por. figura pluskiew w ulotce Ognia (nr 11). Zob. też Cała, Wizerunek Żyda w polskiej kulturze ludowej, dz. cyt. s. 50: [Urzejów, woj. przemyskie] „Żydzi, jeśli się rozmnożą do jakiejś liczby na świecie, to są pogromy”.

91 Tu: C. Kooz, The Nazi Conscience, Harvard University Press, London 2003, s. 201.

92 H. Steinhaus, Wspomnienia i zapiski, dz. cyt., s. 322: „29/07/1945. (...) dowiedziałem się, że w umowie z Sowietami Polska otrzymała prawo sprowadzenia wszystkich obywateli polskich sprzed 1939 roku narodowości polskiej i żydowskiej. Z tego widać, że i teraz Rosja stosuje carską zasadę wypychania Żydów z Rosji".

93 Pismo Kierownika Powiatowego Oddziału Informacji i Propagandy do Naczelnika Informacji i Propagandy w Kielcach na temat Żydów, AAN, MSiP, sygn. 924, k. 103, za: Meducki II, 146.

94 Zob. raporty agentów UB do centrali dotyczące nastrojów społecznych w Kaliszu, Dęblinie i Łodzi w lipcy 1946: „[Kalisz] Następnie puszczono pogłoskę, iż całą ulicę Łódzką będą opróżniać z Polaków, a na ich miejsce przyjdą tysiące Żydów”, za: A. Paczkowski, Raport o pogromie, „Puls“, nr 50, Warszawa 1991, s. 107. 
w ulotce 10, w pogłoskach krążących po Polsce podwaja się, a nawet potraja ${ }^{95}$. Narodziny żydowskich dzieci przedstawiano jako zagrożenie biologicznego bytu narodu polskiego, równoważne poniekąd z mordowaniem dzieci polskich. Pojawia się rozumowanie:

„dzieci polskich“ ubywa, bo są mordowane przez Żydów

$$
\text { = Żydów przybywa }
$$

= (1. przyjeżdżają z Rosji, 2. rozmnażają się dzięki subwencjom) $=$ Polska jest zagrożona $=$,polskie dziecko jest zagrożone".

Wszystkie elementy wywodu mogą się wymieniać i stapiać. Świadczą o tym okrzyki zanotowane w czerwcu 1945 roku podczas napadu na grupę Żydów stojącą na rynku w Zamościu: „Wy Żydzi skurwysyny, (...) ja was wszystkich wyrżnę, przyjechaliście z Rosji nasze dzieci zabijać" ${ }^{\prime 96}$.

\section{Niewdzięczność/wdzięczność}

Podobnymi środkami, to jest przez powtórzenia i paralogizmy, ulotki informują o powinowactwach Żyda Krwiopijcy. Porównuje się go z kryminalistą, folksdojczem i SS-manem7, co zapowiadał cytowany wcześniej, przechwycony przez cenzure list 5, gdzie wystąpiło określenie „żydzi hitlerowscy". Teksty 3 i 9, w których wspomina się o niewdzięczności Żydów przechowywanych w czasie wojny przez Polaków, a następnie mordujących swoich wybawców i współpracujących z Sowietami, odwołują się do starego sylogizmu Żyd = zdrajca. Przemilczaną przesłankę stanowi tu ogniwo "Judasz"

\section{Judasz zdradził Chrystusa-Zbawiciela; Judasz był Żydem; Żydzi to zdrajcy i niewdzięcznicy.}

Motyw zdrady zostaje mitycznie opracowany w omówionym wcześniej toposie "Żydów strzelających do polskich żołnierzy" i "lejących im wrzątek na głowy" (10), który ekspediuje się aż do roku 1921 (tekst 10). Groźby pod adresem Żydów, należące do funkcji "ukaranie“, wyraża się za pomocą przedwojennych haseł „Bij Żydów” (8), „Polska dla Polaków“ (7), albo przez wskazanie alternatywy: emigracja albo śmierć („miejsce wasze jest albo w ziemi, albo w Palestynie", tekst 9).

„Gdy towarzysz Buczyński zalecał aktywowi pow. pińczowskiemu urządzanie masówek w sprawie zajść kieleckich, jeden z towarzyszy Komitetu Powiatowego zaoponował : «jak można iść do chłopów w obronie Żydów, jeżeli Żydówki dostaja po 40 tysięcy zł za urodzenie dziecka? «, Sprawozdanie instruktorów KC PPR z pobytu w województwie kieleckim od 4 do 15 lipca 1946, za: Meducki II, 140. Por. także Łódź 1946: „Robotnicy strajkujący posługują się następującymi antysemickimi argumentami: ciężarna Żydówka otrzymuje 60 tys. zł, a ja co? «", Paczkowski, Raport o pogromie, dz. cyt., s. 72.

96 Akta w sprawie Edwarda Hubala i inni, wystąpienia antyżydowskie, Archiwum Państwowe w Zamościu, Sąd Okręgowy w Zamościu 1918-1950, sygn. 987, za: Kopciowski 182.

97 Zob. dokument sygnowany przez „Polski Ruch Niepodległościowy i Polityczne Kierownictwo Narodu Polskiego", w którym mowa o zainicjowanym przez Żydów systemie rządzenia "godnym metod Gestapo - z tą tylko różnicą, że jest wyrafinowany, maskowany i pozorowany przy użyciu jako narzędzi polskich elementów przestępczych, jakie na marginesie każdego społeczeństwa znaleźć można". Archiwum Państwowe w Krakowie (dalej: APKr), zespół WiN, 41, k. 166: Do Żydów w Polsce, za: Kwiek, Ogień, s. 245. Zob. też ulotka sygnowana "Ogień”, 1945?, miejsce odnalezienia nieznane: „Żydostwo , którego celem jest wytępienie prawdziwego elementu polskiego, nie ma racji bytu (...) Prawdziwe oddziały partyzanckie nie sa żąne krwi bratniej i chęci zysku, lecz walczą o polepszenie bytu dla nas [mas?], uciśnionych przez ZSRR i żydostwo. [...] na podstawie wywiadu i dowodow PDP stwierdzono, że w skład UBP wchodza SS-mani, Volksdeutsche, kryminaliści, bandyci i złodzieje na czele z Żydami i bolszewikami (...)", AAN, zespól Ministerstwa Informacji i Propagandy, sygn. 823, za: Cichopek 32.

98 Zob. J. Tokarska-Bakir, Rzeczy mgliste. Eseje i studia, Sejny 2004, s. 73. 


\section{3. ŻYDZI W DYSKURSIE URZĘDOWYM I LEWICOWYM}

Lewicowy wariant figury Krwiopijcy można zilustrować sprawozdaniami z lat 1945/1946: starostów, wojewodów i innych urzędników państwowych, a także inspektorów przysłanych do województwa kieleckiego w okresie tuż po pogromie kieleckim. Po tekstach oficjalnych trudno spodziewać się szczerości, dlatego na uwagę zasługuje każdy sygnał niechęci do Żydów, przebijający się przez przyjętą retorykę. Tym bardziej że czyni to bez widocznego trudu.

We wszystkich tekstach Żydzi ukazywani są jako posożyty, naciągacze lub wyzyskiwacze, a więc jako kapitalistyczny Krwiopijca, znany z różnych odmian frazeologii lewicowej. Mimo wojny wciąż ma on gigantyczne zasoby, pochodzące ze spekulacji, z subwencji rządowych albo z niemieckich z odszkodowań99, wciąż jednak oczekuje więcej. Zarzuty wobec Żydów ubrane są w terminologię patriotyczną i postępową. Odzywa się w nich ironia, resentyment etniczny, sprzeciw wobec równouprawnienia Żydów i niechęć do oddawania im majątków.

Tekst 1

[Wojewoda kielecki Eugeniusz Wiślicz-Iwańczyk, „Wspomnienia”, lata 50.?]

„Błędy w beztroskim zachowaniu Kieleckiej Gminy Żydowskiej, polegające na jaskrawej różnicy w wyższym poziomie życia bez produkcyjnej pracy ${ }^{100}$, kiedy robotnicy dosłownie głodowali, oraz fakt znacznej koncentracji osób pochodzenia żydowskiego na kierowniczych stanowiskach aparatu bezpieczeństwa i partii zostały przez inspiratorów reakcyjnego podziemia wykorzystane" 101

„Tutaj w Komitecie Wojewódzkim Partii posiadali [Żydzi] swoich współplemieńców. Funkcje I Sekretarza Komitetu pełnił tow. Józef Kalinowski, który mimo iż podawał w Kościele katolickim dzieci do chrztu świętego (tak było w przypadku zaproszenia go do tego obrzędy przez prezydenta miasta Kielc tow. Słonia), nie ukrywał zbytnio swego żydowskigo pochodzenia, o czym wszyscy wiedzieli" ${ }^{102}$.

„.... mała społeczność żydowska [w Kielcach] stała się bardzo widoczna, ponieważ żyła na dużo wyższym materialnie poziomie od spauperyzowanego w czasie długoletniej wojny środowiska polskiego. Drogie garnitury, złote obrączki na palcach, mnogość pieniądza i widoczna niechęć do podejmowania niepopłatnej wówczas pracy nie mogły zostać niezauważone przez środowisko polskie".

Tekst 2

[Prezydent Częstochowy ${ }^{103}$, starosta częstochowski ${ }^{104}$ ]

„Społeczeństwo polskie nie może zrozumieć mniejszości żydowskiej, gdy podejmuje ona zabiegi o powiększenie swego stanu posiadania materialnego i na tej płaszczyźnie najczęściej nie liczy się z faktami, które zaistniały od roku 1939 i gdy mniejszość ta akcentuje, że tylko ona poniosła ofiary w latach wojny. Odwrotnie mniejszość żydowska nierzadko nie ma odczucia dla przemian psychologicznych, jakich dokonały lata okupacji, w społeczeństwie polskim i wymogów chwili, które musiały być zrozumiane przez społeczeństwo żydowskie w ten sposób, że w wolnej demokratycznej Polsce nikt nie ma i nie może mieć przywileju, korzystania z dóbr

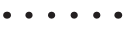

99 Plotki o nich krążły po Polsce w roku 1945: zob. Steinhaus, Wspomnienia i zapiski, dz. cyt., s. 325 „15/08/1945. (...) Stark opowiadał też o kursującej legendzie, że każdy Żyd wracający z obozu ma 10000 dolarów".

100 Na temat poziomu życia Żydów powracających z kryjówek i obozów por. listy komitetów żydowskich z Radomia, Szydłowca, Jedlińska do Wojewódzkiego Komitetu Żydowskiego w Kielcach, które przytacza Penkalla 576- 577.

101 E. Wiślicz-Iwańczyk, „Wspomnienia”, AAN, teczka osobowa nr 8500, s. 443-468, za: Meducki II 83, także Penkalla 569.

102 Oba fragmenty Meducki II 81.

103 Archiwum Państwowe w Kielcach (dalej: APK), UWK/II, sygn. 1283, k. 114-117.

104 Sytuacyjne sprawozdanie miesięczne za miesiąc lipiec 1945 r., przygotowane przez starostę w Częstochowie, APK, UWK/ II, sygn. 1337, k. 329. 
materialnych nez obowiązku czynienia daleko idących świadczeń na rzecz spoleczeństw i państwa. Zresztą obiektywizm nakazuje podkreślić (...), że interes państwa wymaga gruntownego przeanalizowania przez mniejszość żydowską swego dotychczasowego sosunku do społeczeństwa w płaszczyźnie spraw materialnych“105.

Tekst 3

[Prezydent Częstochowy, 9/07/1945]

„pewien konkretny punkt zaczepienia do agitacji antyżydowskiej stanowi fakt znalezienia w dn. 18 czerwca br. w dołach cegielni «Helmana « zwłok 15-letniej Krystyny Woźniak, która została uduszona i wrzucona do glinianek. Pod zarzutem popetnienia morderstwa na osobie tej dziewczynki został aresztowany Chil Teper, krawiec, zam. przy ul. Wolności Nr 15, który został przekazany władzom prokuratorskim i osadzony w więzieniu. Sekcja zwłok nie stwierdziła ani deflo[r]acji, ani też innych uszkodzeń ciała, poza oznakami uduszenia"106.

Tekst 4

[Starosta opatowski, 2/12/1945]

„Z żądań Komitetu Żydowskiego wynika, że ludność żydowska spodziewała się od Rady Narodowej w Ostrowcu, że po prostu pozostanie ona na utrzymaniu Opieki Społecznej, mimo iż posiadała ona odpowiednie zasoby, żyje ona na dość wysokiej stopie, np. konsumuje białe pieczywo, wędliny i zajęła się handlem" ${ }^{107}$.

Tekst 5

[Raport inspektorów KC PPR przebywających w woj. kieleckim od 4 do 15/07/1946]

„W Ostrowcu kilkuset Żydów również nie pracuje. W większości uzdrowisk państwowych siedzą przeważnie bogaci Żydzi i polska reakcja [...] Niezadowolony tłum czuje się pokrzywdzony, chciałby znaleźć winnego i na nim wyładować swoje oburzenie. Wystarczy wskazać tłumowi pewne nieprawidłowości, jak życie niektórych Żydów bez pracy, jak nadużycia spotykane przez PPR-owców lub u władz państwowych, aby tłum obrócić przeciw PPR lub przeciw Rządowi“"108.

Tekst 6

[tamże]

"Dowodem antysemityzmu w szeregach partyjnych będą następujące przykłady. Na wiecu w Ostrowcu tow. Kasior Józef (PPR) występuje z przemówieniem przeciw Żydom, "co to jest, my tu harujemy jak konie, a Żydzi żyją w Ostrowcu jak u Pana Boga za piecem, kupują masło i kury, gdzie byli gdy walczyliśmy w partyzantce? « Tak mówi towarzysz, który przeszedł przez szkołę partyjną, wojewódzką i centralną" ${ }^{109}$.

Tekst 7

9/10/1945, [Kierownik I Wydziału Wojewódzkiego UB, por. Srokowski w Kielcach do Wojewody Kieleckiego]

„na ogół stosunek społeczeństwa do ludności żydowskiej jest nacechowany nieprzychylnością, mającą poniekąd swoje źródła w propagandzie oraz działalności hitlerowskiej podczas okupacji. Nieprzychylność ta i stosunek negatywny wyrażają się w utyskiwaniu i podkreślaniu faktów zajmowania przez Żydów wysokich stanowisk w administracji i w Państwie. Szeroko są między ludnością polską kolportowane pogłoski o rzekomo olbrzymich subsydiach, z których korzystają Żydzi ze strony państwa. Oprócz tego fakt obejmowania przez Żydów swych przedwojennych nieruchomości wywołują wśród ludności pewien rodzaj niechęci"110.

- . . .

${ }^{105}$ APK, UWK/II, sygn. 1283, k. 114-117.

106 Tamże, sygn. 1242.

107 Penkalla 561.

108 Sprawozdanie instruktorów KC PPR z pobytu w województwie kieleckim od 4 do 15 lipca 1946, za: Meducki II, 138.

109 Tamże. Dalej o podobnych głosach z Ostrowca i Pińczowa.

110 Penkalla 572, także Zaremba 111. 
Z języka wypowiedzi wynika, że ich autorzy - starostowie i wojewodowie - przeważnie zgadzają się z relacjonowanymi opiniami (teksty 1, 2, 3, 4, 5). Żydzi przedstawiani są jako grupa separująca się, w najlepszym razie pozostająca na uboczu, nieangażująca w przemiany polityczne (2). W sprzeczności z tą opinią stoi zarzut ich karierowiczostwa, "zajmowania wysokich stanowisk", wysuwany w tekście 1 oraz 7.

Sprawozdający podkreślają lenistwo Żydów niepracujących (tekst 5), niechętnie podejmujących niepopłatną pracę (1), dbających wyłącznie o powiększenie swojego o stanu posiadania materialnego" (2). Nie kryją się oni ze swoim luksusem, na przykład noszą drogie garnitury i złote obrączki (1), jedzą białe pieczywo i wędliny (4), kupują masło i kury i wraz z "reakcją" próżnują w większości uzdrowisk (5). Zestawienie z "reakcją" wzmaga odczucie wyzysku, jakiego dopuszczać się mają Żydzi. Brak zahamowań w epatowaniu bogactwem wojewoda Iwańczyk nazywa nawet „beztroskim“, co ma zapewne sugerować, że mógł on sprowokować robotników (1). Swoje poczucie krzywdy wykrzykuje też robotnik „Kasior Józef" z PPR, który uważa, że robotnicy „harują jak konie”, podczas gdy Żydzi, podobnie jak w czasie wojny, zażywają spokoju „jak u Pana Boga za piecem“ (6). Poczucie krzywdy wzmagają plotki o subsydiach, jakie mają oni otrzymywać od państwa (7) ${ }^{111}$.

Wątkiem, który pojawia się w tekstach tylko dwukrotnie, lecz wiadomo ${ }^{112}$, że wywoływał najwięcej rozgoryczenia, było odzyskiwanie majątków przez Żydów (teksty 2 i 7). Temu zagadnieniu jest w całości poświęcona wypowiedź prezydenta Częstochowy. Łącząc elementy retoryki marksistowskiej ze starymi uprzedzeniami („,stosunek [Żydów] do społeczeństwa w płaszczyźnie spraw materialnych"), w czarnych barwach odmalowuje on przewrażliwioną ${ }^{113}$ mniejszość żydowską w Częstochowie. W związku ze zbrodnią, przypisywaną żydowskiemu krawcowi, prezydent sugeruje, że społeczność jest odpowiedzialna za pogorszenie swojego położenia. Podobnie nastawiony do Żydów jest starosta Opatowa, miasta, w którym położenie Żydów było równie trudne jak w Częstochowie ${ }^{114}$.

111 Por. wspomnienie osoby, która przed pogromem odwiedzała żydowskie schronisko przy ul. Planty 7 w Kielcach: „To był posępny, strasznie posępny, surowy, posępny dom takich ludzi na czarno ubranych, na szaro ubranych, no, smutny bardzo. Smutny i wstrząsający. Ja do dzisiejszego dnia sobie przypominam, że jak z tego domu wyszłam, to tak odetchnęłam, bo tam... jakby to pani wytłumaczyć tę atmosferę tego domu? To taki dom był jak po pogrzebie, wie pani, jak się zbiera pełno ludzi po pogrzebie. Smutni, przygnębieni, przybici. No takie, takie wrażenie tam się odnosiło tego domu (...) ja się pierwszy raz spotykam [z opinią], proszę panią, że ci Żydzi byli bogaci - no, z mojej własnej obserwacji tego tam pobytu, to nie wyobrażam sobie, żeby mieć majątek, żeby mieć pieniądze i żeby mieszkać w takim kołchozie, w takich trudnych warunkach, tak? Oni wyglądali na taką grupę stale wyczekującą, że gdzieś pójdą, gdzieś kogoś odnajdą, gdzieś dopiero zaczną normalne życie. To był taki jak gdyby przejściowy dom. Więc skąd niby ten ma... te majątki?"; Materiały z filmu «Świadkowie» Marcela Łozińskiego (dalej: S), transkrypcja nagrania, maszynopis niepublikowany, s. 44 Por. też inną charakterystyczną opinię z tego samego źródła, s. 52: „ja się ich... tam, nawet bielizny na górę nie poszłam powiesić, tylko wolałam na podwórku powiesić... - A d la c zego to było takie o d raża ją c e? - A bo ja wiem, dlaczego? - C zy oni byli t a c y bie d n i? - Biedni to nie byli, bo oni mieli wszystkiego wbród, bo dostawali z Ameryki. Dostawali, różne paczki, mieli co jeść. Różne... nawet i - można nazwać i delikatesowe (...) jak owoce czy (...) wszystko, czekolada, wszystko mieli... nie mieli (...) A co się stało, to ja... tej przyczyny szukają, ale nikt tej przyczyny nie zna".

112 Zob. Kopciowski 204, Penkalla 2, 59; mordy przy rewindykacji np. Kopciowski 188-189. O trudnościach w odzyskiwaniu majątków zob. Olejnik 358. Zob. tekst Aliny Skibińskiej, Powroty Ocalatych, [w:] Prowincja noc. Życie i zagłada Żydów w dystrykcie warszawskim, B. Engelking, J. Leociak, D. Libionka, Warszawa 2007, s. 505-600.

113 Penkalla 268 - 15/11/1945: „Niektórzy przedstawiciele społeczeństwa żydowskiego sugerują (...) że pewne elementy ze strony ludności polskiej usitują eliminować drogą gwałtu fizycznego z handlu i przemysłu bardziej energiczne jednostki żydowskie. Nie sądzę, żeby przypuszczenie to było słuszne", zob. Penkalla przyp. 58 do s. 568. O tym, że Częstochowskie było terenem szczególnie nasilonej przemocy wobec Żydów w roku 1945, w tym atmosfery pogromowej, zob. Penkalla 268.

114 W Archiwum Państwowym w Kielcach (APK, UWK/II, sygn. 1242) w roku 1945 odnotowano następujące napady na żydowskie placówki w Opatowie: 23/08/1945 próba napadu, 11/12/08/1945 rabunek, także 12/08/1945 wieczorem, 22/08/1945 strzały do punktu żydowskiego przy ul. Młyńskiej 4. 10/09/45 w Opatowie przed Komitet Żydowski zajechało auto wojskowe, zastrzelono członka komitetu Zylberberga, ciężko ranny Erlichman. 19/10/1945 pismo Starosty powiatowego w Opatowie: „śledztwo nie dało rezultatów pozytywnych". 
Ochlokratyczne wykładnie sprawiedliwości społecznej maskowały niechęć władz do zadzierania z ludem, którego antysemityzm stanowił racjonalizację "spontanicznej nacjonalizacji” żydowskich majątków ${ }^{115}$. Żydom, kojarzonym z "panami" do odzyskiwania majątków. Julian Kwiek podaje, że gdy w 1945 w Działoszycach Żydzi zabrali złoto, zakopane w piwnicy, miejscowa ludność sugerowała, że należałoby je upaństwowić117. Przykłady można by mnożyć.

Iwańczyk, wojewoda kielecki z okresu pogromu, przedstawia Żydów jako tych, którzy są wodą na młyn antykomunistycznego podziemia. To drugi tekst, który zestawia ich z "reakcją" (wcześniej miało to miejsce w kontekście "sanatoriów”). Sformułowanie: „wyższy poziom życia bez produkcyjnej pracy“ nie oznacza tylko zwykłego nieróbstwa. Nosi piętno czasów, w których zgodnie z marksistowską ekonomią wszystkich, którzy nie pracowali w produkcji (a więc np. całą dziedzinę usług, jakimi trudnili się żydowscy rzemieślnicy) uznawano za „darmozjadów”. Pogląd o "nieprodukcyjności“ Żydów był marksistowskim odpowiednikiem przedwojennej chłopskiej opinii, że kupcy i rzemieślnicy są próżniakami, bo nie pracują na roli, tj. w jedyny sposób, jaki w chłopskim mniemaniu zasługuje na miano pracy. Ten sposób myślenia byłby może tylko znakiem czasów, gdyby nie został uznany przez władze za lekarstwo na antysemityzm. Leszek Olejnik pisze:

„Reakcją władz na pogrom kielecki było między innymi powołanie na mocy uchwały Rady Ministrów z 2/07/1946 Komisariatu Rządowego d/s Produktywizacji Ludności Żydowskiej na czele z Ignacym Wrzosem. Jest charakterystyczne, że tej pospiesznie wydanej decyzji nie konsultowano z CKŻP, jak też z przedstawicielami PPR w strukturach żydowskich. Nawet pełniący wysokie stanowisko w Prezydium KRN dr M. Szuldenfrei dowiedział się o utworzeniu Komisariatu Rządowego już po zapadnięciu decyzji w tej sprawie. Jak stwierdzał, był zaskoczony że utworzenie tego urzędu nastapiło po zajściach kieleckich - «jak gdyby nic innego nie pozostawało do czynienia « [...] Wydaje się, iż decyzja o powołaniu wspomnianego urzędu oznaczała pośrednio przyznanie przez rząd słuszności rozpowszechnionej w społeczeństwie opinii o małej produktywności Żydów“"118.

Werbalnie lewicowy obraz Żyda Kwiopijcy de facto podtrzymuje zarzuty stawiane Żydom $w$ dyskursie narodowym i religijnym. Tworzy on pole semantyczne złożone z następujących charakterystyk:

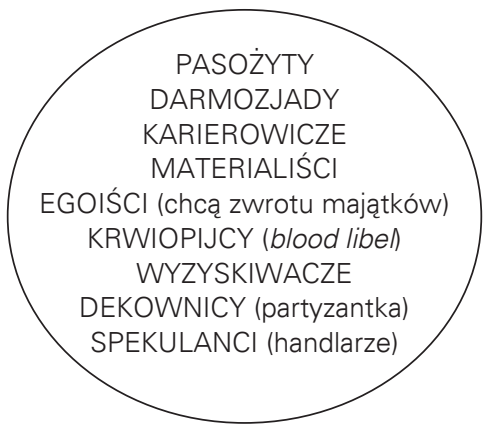

Ryc. 5. Krwiopijca narodowo-lewicowy; na podstawie sprawozdań starostów i wojewodów kieleckich, opatowskich i częstochowskich, lata 1945/1946.

\footnotetext{
$\cdots \cdots$

115 Pisał o tym Stanisław Ossowski (Na tle wydarzeń kieleckich, dz. cyt., s. 51): „jeżeli czyjaś klęska przyniosła komuś korzyść, to u tych, którym korzyść przyniosła, zjawia się często ochota do przekonania siebie i innych, że owa klęska była moralnie uzasadniona, i zauważyłby, że w takiej sytuacji znajdą się na przyklad właściciele pożydowskich sklepów, albo ci, którym kiedyś dokuczała żydowska konkurencja".

116 LK 551

117 Kwiek, Żydzi, temkowie, Stowacy, dz. cyt., s. 73.

118 Olejnik 390.
} 
Niemal identyczne opinie o żydowskim lenistwie, bogactwie, niezasłużonych awansach zawiera tajny meldunek szefa Oddziału Organizacyjno-Instruktażowego Głównego Zarządu Politycznego Wychowania Wojska Polskiego o stosunku żołnierzy do antysemityzmu ${ }^{119}$. Czytamy w nim m.in.:

"Do 39 roku wszystkie bogactwa i fabryki były w rękach żydowskich i teraz będzie to samo" [1 Samochodowy Pułk Łączności WP, szeregowy Bielski].

„Przed wojną mówili Żydzi: nasze kamienice - wasze ulice. A teraz kraj do tego samego dochodzi. Prawie cały przemysł łódzki jest w rękach żydowskich" [7 Samochodowa Inżyniersko-Budowlana Brygada].

„Do ludności żydowskiej nie można mieć pretensji ze względów nacjonalnych, lecz tylko dlatego, że Żydzi przejawiają dążenia przez spekulacje, szukanie lekkiej pracy" [kapral Sieniowski z 3. Dywizji Piechoty] ${ }^{120}$.

„Żydzi zawsze zajmują lepsze stanowiska, nawet w wojsku. Na froncie były tylko jednostki, a pozostali byli w sztabach, magazynach i szpitalach" [strzelec Mankowski z 1. Dywizji Piechoty].

„Wielu Żydów zajmuje wysokie stanowiska w Polsce i nie zależy im na dobrobycie ogółu, i dlatego tak długo nie będzie w Polsce spokojnie, jak długo będą w niej Żydzi" [oficerowie z 9. Dywizji Piechoty].

Poglądy te musiały być powszechne także w środowisku lewicowym poza armią, skoro hasła antyżydowskie wykrzykiwano nawet w czasie pochodu pierwszomajowego w Warszawie w roku $1945^{121}$. Jak podaje Anna Cichopek, o przejawach antysemityzmu w samej PPR mówiono w tym roku trzykrotnie na egzekutywach (7/06 oraz 5 i 19/07/1945):

„W partii jest ferment przeciw Żydom (...) trzeba mieć na uwadze, że obsadzanie stanowisk przez tow. Żydów wywołuje sprzeciw ze strony Polaków (...) w UB nie widać dna bagna. Powszechnie wiadomo, że kierownikami PUBP są Żydzi“"122.

W protokole posiedzenia Sekretariatu KC PPR z 16/08/1945 roku odnotowano słowa Romana Zambrowskiego:

„Nastroje antysemickie istnieją nawet w przodującej części klasy robotniczej. (...) Nie zwalczaliśmy antysemityzmu nawet w naszych organach państwowych"123.

Także Julian Kwiek pisze o antysemickich głosach dochodzących ze środowiska krakowskich partyjnych robotników. W dzielnicy Grzegórzki zarzucali oni władzom, że zbyt

119 Meldunek szefa Oddziału Organizacyjno-Instruktażowego Głównego Zarządu Politycznego Wychowania Wojska Polskiego o stosunku żotnierzy do antysemityzmu, AAN, zespół KC PPR, sygn. 295/VII/166, s. 171 173, za: Cichopek 229-231. Podobne opinie odnotowywano też na innych terenach, np. w Tarnowskiem: „Żydowska narodowość powracająca na teren Tarnowa walczy o specjalne przywileje jak specjalne racje żywnościowe, ukazywanie się na najwyższych stanowiskach administracji państwowej, na stanowiskach najbardziej rentownych, mimo że Żydzi w stosunku do ogółu stanowią minimalny procent. (...) Jak wynika z napotykanych ulotek na murach miasta, z rezolucji uchwalanych przez ugrupowania polityczne i wypowiedzi przywódców tych ugrupowań, istnieje ogólne życzenie społeczeństwa polskiego, aby niepodleglość Polski była rzeczywistością, bo dopóki na naszych terenach istnieje armia obcego, chociaż zaprzyjaźnionego państwa, nie ma mowy o wolności i prawdziwej niepodleglości. Narodowość żydowską uważa się powszechnie jako pomost pomiędzy Związkiem Radzieckim, jego ustrojem gospodarczym i politycznym, a Państwem Polskim, w którym rzekomo wbrew ogólnej woli Narodu Polskiego wprowadza się te same zasady", zob. Wyciąg ze sprawozdania Referatu Spot.-Politycznego Starostwa Tarnowskiego, APKr, WUIP 38, k. 199, za: Cichopek 65.

120 Za: Cichopek 105

121 Notatka Frakcji PPR przy CKŻP, za: Cichopek 51

122 APKr, zespół KW PPR, Egzekutywa, sygn. 1NI/1, k. 7-12, za: Cichopek 61-62. O antysemickich nastrojach w PPR na prowincji i we władzach lokalnych zob. Kwiek, Żydzi, Łemkowie, Stowacy, dz. cyt., s. 56, 57, 6871.

123 AAN, PPR, sygn. 295/NII-1, k. 67-69, za: Meducki II 54. 
wielu Żydów zajmuje stanowiska kierownicze w ministerstwach i aparacie bezpieczeństwa ${ }^{124}$. Na wykładzie w szkole kierowników śledczych MO Komendy Wojewódzkiej, organizowanych jesienią 1945 roku przez Gtówny Zarząd Wychowania Politycznego, instruktor partyjny narzekał na

„niezwykle niski poziom polityczny słuchaczów. Ich wypowiedzi w dyskusji, którą przerywali mi wykład były tego rodzaju: «dopóki Żydzi będą zajmowac stanowiska w Polsce, będzie źle», «jesteśmy pokrzywdzeni przez Żydów, niskie płace nasze i robotnicze to wina Żydów, to ich polityka», "Żydów trzeba wyniszczyć i wygnać», a wyraźne szepty: «precz z Żydami!», «wypędzić Żydów z Bezpieki« itp." "125

W dniu 13 marca 1946 roku podczas konferencji miejskiej organizacji partyjnej w Krakowie pepeerowcy zarzucili członkom PPS, że „ci ostatni prowadzą szeptaną umowę o 17 republice i współpracy z żydami“"126. Na lipcowym wiecu w Dęblinie, zorganizowanym przez PPR po pogromie kieleckim oficjalne przemówienia przerywano okrzykami: „Precz z Żydami”, „Przyjechali bronić Żydów, hańba“, „Żydzi zamordowali trzynaścioro polskich dzieci, a oni przyjechali ich bronić”, „Bierut nie odważy się ich [uczestników pogromu] skazać na śmierć”, "Bronicie Żydów, a jak ja mam przeżyć za 900 zł miesięcznie?”, „Żydzi na czele UB", „Chcemy demokracji, ale bez Żydów"127.

Podobne głosy słychać było w środowisku ludowców. Roman Zambrowski wspominał o wiecach chłopskich, w tym w Woli Żelichowskiej, na którym przyjęta została rezolucja antysemicka ${ }^{128}$. Także w Bochni nieznany z nazwiska mówca zebrał oklaski za to, że

„ nawiązując do referatu [Władysława] Kiernika ${ }^{129}$, w którym stwierdzał, że Polska ma być państwem jednolitym narodowo, postawił wniosek, aby również Żydów wysiedlono z Polski'30, przy czym zaznacza, że Hitlerowi należałoby podziękować za wyniszczenie Żydów“"131.

W oficjalnej interpelacji do Wojewódzkiej Rady Narodowej w Rzeszowie zbliżoną opinię zawarł przebywający po pogromie na terenie Rzeszowa delegat Izby Kontroli Państwa, Adam Popowski. Uznał on, że władze powinny Żydów „traktować jak Ukraińców“132:

„z większym pożytkiem dla obu narodów byłoby wykorzystanie zdolności organizacyjnych i politycznych polskich Żydow na terenie Niemiec, jako posiadających znajomość języka niemieckiego, a zatem mogących opanować prasę, radio oraz ważniejsze dziedziny życia gospodarczego i politycznego. Fama głosi, że nikt inny jak właśnie Żydzi są jedynym narodem,

......

124 Archiwum Państwowe Kraków, PPR, 9, k. 21; Protokół z posiedzenia egzekutywy Komitetu Wojewódzkiego PPR w Krakowie z 5/07/1945, za: Kwiek, Żydzi, Łemkowie, Słowacy, dz. cyt., s. 68.

125 Cytat za: J. Kochanowski, Do raportu! „Polityka“ nr 7: 2000, s. 72, za: Cichopek 103.

126 Tamże, 169, k. 8; Protokót z plenum Komitetu Miejskiego odbytego 9/01/1046, za: Kwiek, dz. cyt., s. 69.

127 Dzieje Żydów w Polsce 1944-1968. Teksty źródłowe, oprac. A. Cała, H. Datner-Śpiewak, ŻlH, Warszawa 1997, s. 71. W dzień egzekucji sprawców pogromu kieleckiego miały zastrajkować wszystkie fabryki łódzkie, za: Steinhaus, Wspomnienia i zapiski, dz. cyt., s. 359. Także w „browarze w Radomiu robotnicy przeciwstawili się rezolucji antypogromowej. Również w spółdzielni i Dyrekcji Lasów Państwowych sprzeciwiano się rezolucji potępiającej zbrodnię kielecką", Sprawozdanie instruktorów KC PPR z pobytu w województwie kieleckim w czasie od 4 do 15/07/1946, za: Meducki II, 138; zob. także Kopciowski 198.

128 AAN, PPR, sygn. 295/NII-1, k. 67-69, za: Meducki II 54.

129 Działacz ruchu ludowego, przywódca Stronnictwa Ludowego Roch, minister administracji publicznej w rządzie Edwarda Osóbki-Morawskiego, zob. Notatka złożona przez Centralny Komitet Żydów Polskich wicepremierowi Władysławowi Gomułce dotycząca rozmów przedstawicieli CKŻP przeprowadzonych w Ministerstwie Bezpieczeństwa Publicznego, w Ministerstwie Sprawiedliwości i w Ministerstwie Administracji Publicznej, 30/09/1945, za: Meducki Il 61-62.

130 Zob. także Wyciąg ze Sprawozdania Referatu Spoteczno-Politycznego Starostwa Tarnowskiego, AOKr., zespół Wojewódzki Urząd Informacji i Propagandy, 38, k. 199: cyt. za: J. Kwiek, Dzieje ludności żydowskiej w Tarnowie po /l wojnie światowej, „Kwartalnik Historii Żydów”, nr 3(215): 2005, s. 361.

131 Pismo Starosty pow. bocheńskiego do Urzędu Wojewódzkiego w Krakowie, 28/08/1945, za: Cichopek 62.

132 Pismo Zygmunta Kratki, dyrektora Departamentu Polityczno-Wychowawczego w Ministerstwie Informacji i Propagandy do Biura Kontroli Państwa w sprawie interpelacji pracownika Biura, Adama Popowskiego: „Zdaniem jego jako czynnika kontroli, należało podać, że zbrodni dokonali Żydzi, że nie ma tu dla nich miejsca, że należy ich traktować jak Ukraińców itp.", za: Kaczm. 116, dok. nr 22. 
który przy odpowiednim poparciu mógłby przyczynić się do zupełnej pacyfikacji Niemiec, a także ściągnąć bezpośrednio należne im odszkodowanie z tytułu strat, tak moralnych, jak materialnych" ${ }^{\prime 33}$.

W wypowiedzi tej wyraźnie widać, że właśnie „kwestia żydowska” stwarzała okazję do zbliżenia pomiędzy frazeologią lewicową i narodową. Dla uważnego czytelnika przedwojennych odezw ONR-owskich, postulujących reformę rolną i nacjonalizację przemysłu$^{134}$ ta bliskość nie jest niczym nowym. Nowością jest siła oddziaływania tych wyobrażeń w komunizującej się powojennej Polsce.

W sposób dosadny, przywołując potrójną figurę Krwiopijcy, wszystkie te opinie podsumowała pewna kobieta w ciężarówce przewożącej ludzi z Sosnowca do Katowic:

„Żydzi nie pracują, lecz wy sys a ją krew na rodu, trzeba ich z powrotem powsadzać do Majdanku i Oświęcimia, jak robili to Niemcy, w Krakowie mordowali dzieci, w Katowicach też już zamordowali pare dzieci. (...) Ja bym z Żydów pasy darła"135.

\section{KONKLUZJA}

Jan Vansina, autor klasycznej pracy o tradycji ustnej jako źródle historycznym, stwierdza:

„pogłoski, którym się nie zaprzecza, przeżywają i wchodzą do zasobu historii mówionej, która następnie staje się ustną tradycją. (...) W procesie kursowania pogłoski wytwarza się zbiorowa świadomość historyczna. Zbiorowe interpretacje wynikające z powszechnie kursujących pogłosek produkują powszechnie akceptowane interpretacje wydarzeń, non-events, i układów zdarzeń. Dlatego też tradycja oparta na pogłosce mówi nam więcej o mentalności czasów, w których się pojawiała, niż o samych zdarzeniach, których dotyczy. Podobnych tradycji nie wolno traktować jako niedorzecznych i relegować na badawczy margines, by potem przywoływać w charakterze ozdobników. Ich przetrwanie w tradycji coś oznacza w kategoriach świadomości historycznej, współczesnej mentalności i ideologii" ${ }^{136}$.

Może się wydawać absurdalne, że kraj otoczony rzeczywistymi wrogami wymyśla sobie wrogów symbolicznych i przeciw nim kieruje swoje siły, jednak to, co ludziom myślącym w pojedynkę wydaje się irracjonalne, w logice wspólnot wyobrażonych wcale takie nie jest. Za wyborem tym oprócz kilkuwiekowej tradycji zwalczania wroga wewnętrznego, a także wzmocnionego przez wojnę i stalinizm narodowego charakteru wspólnoty stał nakaz ratowania poważnie naruszonej spójności społeczeństwa. Wobec zmian, jakie przyniosła wojna, a następnie wyzwolenie kraju przez Armię Czerwoną wspólnota wyobrażona reagowała poniekąd racjonalnie: zwieraniem szeregów. Narzędziem tego pojednania była figura Żyda Krwiopijcy, występująca w Polsce w trzech dyskursach: religijnym, naro-

\section{- •.・}

133 Pismo Adama Popowskiego, inspektora Biura Kontroli Państwa przy Prezydium KRN, do Prezydium WRN w Rzeszowie, 14/06/1945, za: Kaczm. 84.

134 Por. "Sztafeta” (dodatek nazwyczajny), 14/04/1934, Program Obozu Narodowo-Radykalnego: „Ruch ten [mowa o Ruchu Młodych, z którego wyrastał ONR] potrafił niegdyś na łamach akademickich oczyścić życie młodzieży z wpływów żydowskich, a - jako Obóz Wielkiej Polski - objąć masy chłopów , robotników, mieszczan i inteligentów, zatrzeć różnice klasowe i dzielnicowe i sprawić, że młode pokolenie jest bardziej polskie z krwi i ducha”; "Prawo do posiadania ziemi polskiej ma przede wszystkim chłop polski. Państwo powinno dążyć do wytworzenia jak największej ilości drobnych i średnich gospodarstw przez parcelację wielkich obszarów rolnych «latyfundiów « Żydowskie pośrednictwo w handlu produktami rolnymi, będące źródłem nędzy wsi polskiej musi być usunięte. Ciągle umniejszanie majątku narodowego przez kapitał międzynarodowy winno być przerwane przez wywłaszczenie i unarodowienie zakładow użyteczności publicznej, oraz wielkich przedsiębiorstw górniczych, hutniczych i elektrowni opartych na kapitale obcym".

135 Wcześniej wykrzykiwała ona w samochodzie ciężarowym, przewożącym ludzi z Katowic do Sosnowca, za: Zaremba 107-108.

136 J. Vansina, Oral Tradition as History, London 1985, s. 6-7. 
dowym i lewicowym. Po drugiej wojnie światowej, gdy zagrożona suwerenność w sposób oczywisty uprzywilejowała dyskurs narodowy, wszystkie one spotkały się pod sztandarem obrony niepodległości.

Mechanizmem, który uruchamiał antyżydowską przemoc, w tym wszystkie poza jednym powojenne pogromy, było zrównanie symboliczne, proces udosłownienia figury Krwiopijcy. Żyd, pojmowany jako metaforyczny wampir, żywiący się krwią Narodu, pod wpływem plotek o porwanych dzieciach na powrót przekształcał się w porywacza i mordercę, znanego z religijnej blood libel. Jak zauważyła Krystyna Kersten, to właśnie ta dosłowna figura, nie zaś wieści o żydowskich katach w UB, wyprowadzała „pogromszczyków" na ulicę ${ }^{137}$.

Do II Soboru Watykańskiego przekazu o żydowskim mordzie rytualnym Kościół katolicki nie wyłączył ze swojego nauczania. Jak udowodnił Arieh Kochavi, analizując watykańskie stanowisko wyrażone po pogromie kieleckim ${ }^{138}$, wiara w prawdziwość legendy o krwi z całą pewnością nie ograniczała się do polskiego katolicyzmu ludowego, byłoby zatem błędem myśleć o niej w kategoriach „zwykłego przesądu“ niezmodernizowanych wschodnich Europejczyków ${ }^{139}$. Wiara w mit krwi, udzielającąca się biskupom, inteligentom i oficerom podziemia, stanowi zjawisko rodzajowo odmienne od tego, co stanowi bezwładną pozostałość wierzeniową, podobną wierze w króliczą łapę czy czarnego kota. W Polsce podzielały ją wszystkie kręgi społeczeństwa, nie tylko lud, ale elity władzy, w tym hierarchia kościelna, oficerowie armii podziemnej, a nawet funkcjonariusze $\mathrm{MO}$ i niektórzy komunistyczni urzędnicy. Bez dostrzeżenia tej kwestii nie sposób zrozumieć ani powojennego eksodusu Żydów z Polski, ani ewolucji polskiej wersji komunizmu, która rozpoczęła się z tak licznym ich udzialem, kończyła zaś w kraju zupełnie bez Żydów.

THE FIGURE OF THE BLOODSUCKER IN POLISH RELIGIOUS, NATIONAL AND LEFT-WING DISCOURSE, 1945/1946: A HISTORICAL ANTHROPOLOGY STUDY

\section{Sum mary}

Despite the fact that after 1945 all anti-Jewish pogroms in Poland (except one) were given a blood label-a rumor about Jewish murderers of Polish children - this fact has not attracted the attention of historians until recently. Conspiracy theories, however, were a lot more popular and noted that the pogroms had been provoked by "Soviet advisers" or "syonists." The author of this essay argues that participants of anti-Semitic violence, the assailants as well as policemen, prosecutors, and judges involved in controlling the events - though they represented a variety of different political approaches - were all united by a common socio-mental formation, and remained united by a figure of the Jew as bloodsucker (this mystic figure is described here according to Mary Douglas). Many of them, security and secret services functionaries included, succumbed to a suggested blood libel. Moreover, some traces of blood libel are still present in Poland, not only as folk beliefs (cf. the research conducted under the present author's direction in Sandomierz).

137 Kersten 190

138 A. Kochavi, Polscy biskupi, Watykan i Żydzi polscy w czasie przejmowania władzy przez komunistów na podstawie brytyjskich raportów dyplomatycznych, "Zagłada Żydów”, t. 5, Warszawa 2009, s. 159. Przytaczam konkluzję: „Brytyjczycy zrozumieli, że Watykan w pełni akceptuje historyjkę o kieleckim dziecku, nazywanym «Erico Baslzozyk» (w rzeczywistości chłopiec nazywał się Henryk Błaszczyk), który został porwany w celu utoczenia mu krwi".

139 O pogromach wskutek pogłoski o krwi na Węgrzech i Słowacji, zob. np. Kersten I, 134; tam też o pogromie w Velkich Topolanach, gdzie „tłum zaatakował nożami lekarza Żyda, który szczepił dzieci”. 
The essay's aim is to present a structural background of slow growing "Polish national socialism" on the one hand and old anti-Jewish resentments on the other, as both were a ground for a specific anti-Jewish alliance in the first period after World War II. Thus, the author claims that a synthesis of religious anti-Semitism ("Jew-kidnapper-bloodsucker"), modern anti-Semitism ("Jew-capitalist-bloodsucker") and the "Judeo-communists" occurred in Poland, which crippled a healthy body of the nation and the communist party.

The essay is based on, inter alia, letters intercepted by the censorship in 1946, the reports made by some anti-communist underground fighters, a number of memories and documents of communist secret services officers, as well as documents accumulated in the course of investigations held by the authorities after the pogroms of 1945 and 1946.

Keywords: blood-libel legend, Jews in Poland, aftermath of the Holocaust in Poland, anti-Semitism 